\title{
Conversion and Political Expedience: Imperial Themes in the Early Christian Baptistery
}

\section{Imperium and Sacerdotium}

$\mathrm{N}$ THIS STUDY I wILl ARGUE that the changing political climate in Early Christian and Byzantine periods had an important impact on the symbolic understanding of the baptistery as a place of initiation into a state religion. ${ }^{I}$ Central to this argument is the way in which the relationship between imperium and sacerdotium found expression in the ritual and architectural developments of the baptistery. I propose to explore this relationship in the cities of Rome, Constantinople and M ilan through an examination of the architectural setting of the baptismal rite and other related or supporting rituals. The study will examine two themes that underlie the political dimension of baptism. ${ }^{2}$ The first concerns the shaping of the identity of the

I. The most important studies on the Early Christian baptistery are: Giovanni Giovenale, II Battistero Lateranense, Studia di Antichita Cristiana, Rome, Pontificio Istituto di Archeologia Cristiana, 1929, vol. I; J.G. Davies, The Architectural Setting of Baptism, London, Barrie and Rockliff, I962; A. K hatchaterian, Les baptistères paléochrétiens, Paris, 1962. For an in depth investigation of the archaeological, iconographic and cultural contexts of a baptistery see Spiro Kostof, The O rthodox Baptistery of Ravenna, N ew H aven Connecticut, Yale U niversity Press, 1965.

2. On the symbolism and meaning of baptism see in particular D.G. D unn, Baptism in the H oly Spirit, London, scm Publishers, I970; G.R. Beasley-M urray, Baptism and the N ew Testa- 
Christian emperor as overseer of conversion, and how this identity was variously affirmed or countered by Early Christian doctrine. The second relates to the transformation of urban topography as a metaphor of the changing relationship between pagan and Christian traditions. M y aim is to highlight the manner in which the Christianization of imperium found expression in the symbolic understanding of topography where the drama of Early Christian conversion took place. A large part of the study will be devoted to Constantinian Rome where sacrament and topography, ritual and urban space, forged a complex and problematic alliance that helped delineate a passage of redemption from a state of decrepitude and sin to one of salvation. I will argue that the redemptive implications of topography in the Rome of Constantine anticipate St. Augustine's theological doctrine of two cities, civitas terrena and civitas dei. The examination will focus on the following church complexes, each of which emerged out of a unique political situation; the Lateran and St. Peter's in Rome, Santa Tecla in M ilan and Blachernae in Constantinople.

\section{Burial, Resurrection and Reception}

At the heart of the Pauline D octrine of baptism is the notion of the rite as a re-enactment of the death, burial and resurrection of $\mathrm{C}$ hrist. ${ }^{3}$ This meaning was not only expressed in the liturgy of the rite but also had a bearing on the formal and symbolic developments of the baptistery. Richard $K$ rautheimer recognized this fact in his study of the iconography of Early Christian and M edieval architecture in which he identifies two architectural influences on the form of the baptistery; the bath-building and the

\footnotetext{
ment, Exeter, England, Paternoster Press, 1979; Gunter Wagner, Pauline Baptism and the Pagan M ysteries, trans. J.P. Smith, London, O liver \& Boyd Publishers, 1967. A more incisive examination of the rite in its changing cultural context, which is also an important source for this article, is Peter Cramer, Baptism and Change in the Early M iddle Ages, Cambridge, England, Cambridge U niversity Press, I993, and also J oseph N. Fete, "The Cultural Background of the Roman Ritual of Baptism" (unpublished thesis, Divinity School, Yale U niversity, 198I).

3. See W agner, op. cit.

4. Richard Krautheimer, "Introduction to an 'I conography of M edieval Architecture'", J ournal of the Warburg and Courtauld Institutes, vol. 5 (1942), pp. I-33.
} 
imperial mausoleum. ${ }^{4}$ The former influence is based on a long-held association of circular domical buildings with the practice of bathing or water ablutions. 5 In the second influence, Roman sepulchral architecture particularly of the $3^{\text {rd }}$ and $4^{\text {th }}$ centuries, the author identifies certain features that have striking similarities to many Early Christian baptisteries, notably the "combination of a vaulted centre-room with either an inner or closed and relatively low, outer ambulatory". ${ }^{6}$ Whilst domical and centrally planned spaces in Antiquity and Early Christianity had multivalent meanings there existed, I would argue, a more enduring association that centres on funereal/mortuary symbolism. ${ }^{7}$ Concurrent with these architectural developments in Late Antiquity and Early Christianity was a renewed emphasis on the immortality of the deceased emperor, as indicated in the special importance attached to the Roman ceremony of the consecratio during this period. ${ }^{8}$

Besides the two Roman influences highlighted by Krautheimer another ancient model may have contributed to the iconography of the baptistery. This is the imperial reception hall. 0 ften domical with a circular or octagonal plan, the hall functioned as a ceremonial space between the emperor, his court and the gods. Perhaps the best-known early example is the octagonal hall of Nero's D omus Aurea, the form and structure of which reveal impor-

5. There is evidence that some Early C hristian baptisteries were actually built on, or near to, the sites of ancient bath-buildings, no doubt to utilize the existing water supply. Besides the Lateran Baptistery, the Orthodox Baptistery in Ravenna is the most commonly cited example in Early Christianity. Also, next to the Baptistery of D jemila there is a small bath-building, presumably for pre-baptismal ablutions.

6. Krautheimer, op. cit., p. 25.

7. Certainly by the time of the construction of the Anastasis R otonda in Jerusalem, the supposed site of Christ's burial, the use of round or polygonal structures for the burial of a venerated 'hero' had become common practice. H owever, compared to other ancient civilizations, traditional Roman religion generally had a fairly dim view of afterlife, even considering the practice of consecatrio when immortality was conferred on the deceased emperor. It is likely, in this respect, that the specific attribution of centralized domical buildings as symbols of resurrection was a largely Christian innovation, as we see for example in martyria. This symbolism, which became prototypical of many "versions" of the Anastasis Rotonda in Europe and the M iddle East, was central to the iconography of the baptistery that gave meaning to the idea of individual salvation as rebirth from a former life of sin.

8. Sabine M acC ormack, Art and Ceremony in Late Antiquity, Berkeley, U niversity of California Press, 1981, pp. 97-98, I07-109, and I19-121. 
tant innovations in Roman architecture during this period. The ceremonial function and cosmic symbolism of the octagonal space signaled an elevation of the status of the emperor as living deity, which in the case of $N$ ero related specifically to his incarnation as Helios and the Persian M ithra. 9 From the period of Constantine onwards, the circular/polygonal throne room or reception hall became a common feature in imperial palaces, as seen for example in Constantinople. ${ }^{\text {to }} \mathrm{M}$ uch like its pagan predecessors, the throne rooms and banqueting halls of the Christian emperors were conceived as convivial settings for ritual dialogue between emperor and divinity. ${ }^{\text {II }} \mathrm{O}$ ne possible example is the so-called Golden $O$ ctagon in Antioch, which according to Krautheimer may have functioned as imperial throne room and court chapel under Constantine, given its location close to the imperial palace.

Serving as the ritual and symbolic threshold to the basilica, the baptistery acquired certain distinctive characteristics. The theme of reception was particularly germane to baptismal symbolism since the efficacy of the rite as redemptive passage to salvation assumes an eschatological meaning. This was typically conveyed in iconographic terms as an assembly of witnesses to the event. The mosaics of the $5^{\text {th }}$ century 0 rthodox Baptistery at Ravenna clearly demonstrate this; the dome and lower drum are embellished with a profusion of Old and New Testament figures, prophets and apostles, and apocalyptic references, hierarchical arranged in concentric bands that center on a representation of Christ's baptism in the Jordan at the crown. Among these latter references are images of the vacant throne, a motif that is particularly important to the eschatological symbolism of baptism. These motifs alternate with altars in the lower ring of mosaics in the dome and are represented in a walled garden evocative of paradise. Shown draped and bejeweled, the vacant throne probably refers to two distinct yet inter-related themes. The first derives from Biblical sources such as Ezekiel (r:26) and Psalm 89, the latter invoking Christ's second coming: "Justice and judgment are the habitation

9. O $\mathrm{n}$ the subject of $\mathrm{N}$ ero as $\mathrm{M}$ ithra and its significance in the iconography of the D omus Aurea, see H .P. L'O range, Studies on the I conography of C osmic Kingship in the Ancient W orld, Instituttet For Sammenlignende Kulturforkning, O slo, H. Aschehoug, 1953, pp. 28-34.

Io. Richard Krautheimer, Early Christian and Byzantine Architecture, $\mathrm{H}$ armondsworth, Penguin Books, 1979, pp. 74-75; Richard Krautheimer, Three Christian Capitals: T opography and Politics: Rome, Constantinople, M ilan, Berkeley, U niversity of California Press, 1983, pp. 49-50.

II. For a selective bibliography on the symbolism of Late Antique and Byzantine reception halls see Richard Krautheimer, Early Christian and Byzantine Architecture, p. 493, n. 23. 
DOI: http://dx.doi.org/10.22201/iie.18703062e.2002.80.2105

of thy throne; mercy and truth shall go before thy faces." This was to form the basis of the symbolism of the H etoimasia, or prepared throne of Christ's second coming. The second association pertains to kingship and concerns the numinous presence of the emperor or king, a symbolism that derives from the Roman imperial cult and the earlier H ellenistic ceremony of Cyinda. ${ }^{12}$ The symbolism was later to become a dominant theme in Byzantine court ceremonial, in which divine kingship was supported by the symbolism of the Hetoimasia and Christ Pantocrator. The mosaics in the sanctuary of San Vitale in Ravenna are a good example of this.13 The incorporation however of the vacant throne in the mosaics of the $5^{\text {th }}$ century 0 rthodox Baptistery during the period of the joint-reign of $\mathrm{H}$ onorius in Ravenna and Arcadius in Constantinople, that predates the development of Byzantine court ceremonial, seems to suggest a conflation of Judeo-Christian apocalyptic themes and references to the Roman imperial cult. ${ }^{14}$

It is conceivable that the Roman tradition of the domical reception hall as an essentially revelatory and cosmic space, that affirms the privileged sta-

I2. "A decree... designating Caesar dictator perpetuo, granted him a golden chair for the theatre as well, not for his personal use but for his golden crown to be placed on it... Such chairs were set up in honour of the gods in the East and in G reece, and were also used for the banquets of the gods, the theoxenia." Stefan W einstock, Divus Julius, O xford, O xford U niversity Press, 197I, p. 6; on the symbolism of the vacant throne in the hagiography of Alexander the G reat see Charles Picard, "Le T rône vide d'Alexandre dans la C érémonie de C yinda et le culte du Trône vide à travers le monde G réco-Romain," Cahiers Archéologiques Fin de I'Antiquité et M oyen Âge, VII (I954), pp. I-I7, figs. I-v. W ith influences drawn from the 0 riental cults, solar symbolism became especially prevalent in the imperial cult of Late Antiquity as witnessed for example in representations of the emperor Aurelian.

I3. For an examination of the mosaics of San Vitale see 0 tto G. von Simson, Sacred Fortress: Byzantine Art and Statecraft in Ravenna, Princeton, Princeton University Press, 1987, pp. 23-39.

I4. Influence of the imperial cult finds some support by the similarity of the mosaics of the $\mathrm{O}$ rthodox Baptistery to those of the domical Church of $\mathrm{H}$ agios Giorgios, formerly the $\mathrm{M}$ ausoleum of Galerius in Salonika. John Beckwith's interpretations of the imperial themes of $\mathrm{H}$ agios Giorgios could equally be applied to the Orthodox Baptistery in Ravenna: "In the years of its triumph the Church naturally related to the ceremonial of the imperial court for the symbolic expression of divine authority and power. The mosaics of $\mathrm{H}$ agios $\mathrm{G}$ iorgios express the glory of Roma aeterna in a new $\mathrm{C}$ hristian guise and pay homage to $\mathrm{C}$ hrist who is the true founder of the $\mathrm{H}$ oly $\mathrm{C}$ ity. In this case we have a direct expression of the art of the imperial court... " John Beckwith, Early Christian and Byzantine Art, H armondsworth, Penguin, 1979, p. 32. 
tus of the emperor as a semi-divine figure, informed the ritual and symbolic function of the Early Christian baptistery. As Peter Cramer suggests, "The baptistery is the triumphal building, the Pantheon. It preserves the association of the dome with the starred sky and therefore with military and political power." Is

Like the imperial reception hall, the Early C hristian baptistery functions as a transcendent space that enables communication between the heavenly realm and the individual supplicant. In this case, however, the humble neophyte rather than the emperor is the focus and beneficiary of the ritual. For the baptismal rite, redemptive passage is registered ritually by the descent into, and ascent from, the water of the font that is symbolic of the death, burial and resurrection of $\mathrm{Christ}$.

Taken therefore as exemplary models, the three influences outlined above, as they pertain to acts of bathing, burial and reception, could be said to underlie the most important symbolic associations of the Early Christian baptistery. These moreover informed lesser known cathartic or purification rituals in the Eastern empire that were baptismal in nature but specifically associated with imperial rule. This can be seen in a complex of buildings at Blachernae in Constantinople that dates back to the $5^{\text {th }}$ century and which later became a monastery. Located at the northern extreme of Constantinople, just outside the Theodosian walls and along the Golden $\mathrm{H}$ orn, Blachernae was long venerated as the site of a sacred spring. ${ }^{16} \mathrm{~A}$ number of buildings were erected in its vicinity, notably an imperial palace that contained a number of triclinea, a basilica with an adjacent circular chapel (soros) and what has been described as a bathhouse (louma). O riginally built by Empress Pulcheria (ca. 450), the church is dedicated to the Virgin M ary and became a place of pilgrimage throughout the Byzantine age. This was largely due to

I5. C ramer, op. cit., pp. 269-270.

16. 0 xford Dictionary of Byzantium, Alexander P. Kazhdan (editor-in-chief), N ew York, O xford U niversity Press, I99I, p. 293; R. J anin, Constantinople Byzantine: D éveloppement U rbain et Répertoi re T opographique, Paris, Institut Français d'Études Byzantines, 1950, pp. I24-I25.

I7. Brought to Constantinople from Palestine, the relic became central to the cult of "H agiosoritissa" in Byzantium. It is conceivable that the cult was related in some way to the sacred spring, in view of the numerous rituals of purification that took place here. In one of the triclinium in the Imperial palace, called the "O cean" on account probably of its interior embellishments, there took place an annual ceremony of purification on February 2 that was officiated by the emperor. Traditionally in pagan religion this date celebrates the coming of 
DOI: http://dx.doi.org/10.22201/iie.18703062e.2002.80.2105

the presence of the robe of the Virgin in the circular chapel constructed by Emperor Leo I (457-474). ${ }^{17}$

The reliquary shrine was located next to the spring that probably supplied water to the nearby "bathhouse". Archaeological and textual evidence of this latter structure suggests that it had a more specific ritual function than simply bathing. Byzantine court ritual comprised a complex blend of classical vocabulary, particularly as it relates to imperial ceremonial, and Christian thought. ${ }^{18}$ According to the ${ }^{\text {to }}{ }^{\text {th }}$ century Book of Ceremonies, attributed to the emperor Constantine VII Porphyrogenetos, a ceremony dedicated to the cult of the Virgin took place in the Byzantine court, in which the emperor was immersed thrice in a pool of water, much like triple immersion in baptism. ${ }^{19}$ It is conceivable that this took place in the so-called bathhouse at Blachernae where water poured from the breasts of a statue of the Theotokos, or mother of God. Excavations have revealed a polygonal apsidal structure that could be likened to a baptistery. ${ }^{20}$ W hilst it would be simplistic to claim that this building functioned as a baptistery it seems clear that its ritual function was influenced in some way by baptismal symbolism. The unusually large pool in the middle of its enclosure gives further support to the idea that it was used for some form of ritual ablution.

Spring and was associated with female fertility. It later became the Christian festival of $\mathrm{C}$ andlemass, or feast in honor of J esus.

I8. For a general discussion of this see M acCormack, op. cit., pp. 222-259; M ichael M cC ormick, Eternal Victory: T riumphal Rulership in Late Antiquity, Byzantium and the Early $M$ edieval W est, Cambridge, Cambridge U niversity Press, I990, pp. I3I-I84.

I9. Constantine Porphyrogenetos, Book of Ceremonies, Patrologia Graeca, II2, Bonn Corpus, pp. 9-ıо; A. Vogt, Le Livre des Cérémonies, Paris, I935, Book I; J.B. Bury, "T he Ceremonial Book of Constantine Porphyrogenetos", EHR 22, 1907, pp. 209-213.

20. Krautheimer asserts that it is unlikely that the building was a baptistery. See Early Chris tian and Byzantine Architecture, p. 497, n. 8. M oreover, the building was probably a "hagiasma ('baptistery' of the Church of the Virgin M ary H odegetria) serving a cult of the Theotokos in which a sacred spring or fountain figures prominently. $O$ thers belonging to the group existed in the Church of the Theotokos of the Spring and in the Church of the $\mathrm{H}$ oly soros attached to the larger $C$ hurch of the Theotokos at Blachernae where the Emperor went annually and thrice entered the sacred fountain in a ritualistic bath that was definitely not baptism. Whatever function of the font at $\mathrm{H}$ odegetria, it borrowed from the iconography of baptisteries in employing octagonal font within the hexagonal building." Constantine Porphyrogenitus, D e ceremoni is aulae Byzantinae, Reiske (ed.), pp. 554-556. 
The evidence at Blachernae suggests an affinity between the cult of the Virgin and imperial ceremonial, a relationship that can be found elsewhere in numerous mosaics of the Byzantine period. ${ }^{2 \mathrm{I}}$ The Virgin cult centered around the notion of "Theotokos" which was originally formulated at the council of Ephesus in $\mathrm{AD} 43 \mathrm{I} \mathrm{r}^{22}$ As the critical link between divinity and humanity, the idea of $M$ ary as bearer of $G$ od was to provide one of the main theological underpinnings for the integration of C hurch and state in Byzantium. In the case of Blachernae, the cult of the Virgin and the imperial cult were combined in such a way that the effectiveness of imperial rule relied on the continuing veneration of the Virgin. This is suggested in an account of a ceremony that celebrated the end of two sieges in the $7^{\text {th }}$ century against the Avars, Slavs and Persians:

a more formal ceremony was organized, in which the junior emperor [H erakleios] and the patriarch [Sergius] conducted a procession out of the city to the shrine of the Virgin of Blachernae. The devotion to the V irgin and the appeal to her relics which marked both sieges played a key role in the crystallization of the capital's special cult of M ary, the source of Roman victory. ${ }^{23}$

The procession entailed the return of the holy robe of the Virgin to Blachernae that had earlier been transferred to $\mathrm{H}$ agia Sophia for safe-keeping during the siege. M iraculously, the Church of the Virgin survived the siege and Emperor H erakleios extended the Theodosian wall to enclose Blachernae so

2I. See in particular the mosaic over the south doorway where the Emperor Constantine is shown presenting a model of the city, and J ustinian one of the church, to the enthroned Virgin.

22. The decree made at the Council of E phesus that "Theotokos" is orthodox was the result of a long and protracted conflict that raged in Constantinople between N estorius, the city's bishop, and empress Pulcheria. In N estorius' view no mortal could give birth to the Godhead. Therefore, M ary bore a man, the "vehicle of divinity" but not God. Consequently, the bishop advocated the title "Theodochos." See Richard A. N orris Jr. (trans. and ed.), The Christological Controversy, Philadelphia, Fortress Press, 1980, p. І3I. For an examination of the controversy and the central role played by the Virgin in the Eastern Empire see Vasiliki Limberis, Divine H eiress. The Virgin M ary and the Creation of Christian Constantinople, London, Routledge, 1994, esp. pp. 53-61.

23. M CC ormick, op. cit., p. 76. This is in reference to $\mathrm{N}$ icephorus I, Breuiarium, C. de Boor (ed.), Leipzig, I88o, pp. 18, 24-27.

24. 0 xford Dictionary of Byzantium, p. 29.

25. This continued right up until the fall of Constantinople in the $15^{\text {th }}$ century under the 
that it would form part of the city. ${ }^{24}$ Subsequently, the palace at Blachernae became increasingly important as an imperial residence. ${ }^{25}$

Understood topographically, the location of Blachernae at the periphery of the city could be compared to the venerated sites of the martyrs outside the Aurelian wall of Rome that were similarly vulnerable to attack during times of foreign invasion, most significantly the Sack of Rome of AD $4 \mathrm{IO}$. W hat differentiates, however, Constantinople from Early Christian Rome is the way in which Byzantine court and church ceremonial were integrally related and gave cohesion to the symbolic and ritual topography of the city. ${ }^{26}$

In spite of this difference, however, a comparison could be drawn between the imperial residence of the basileus (emperor) at Blachernae and the palatium of the Roman bishop at the Lateran. W hat was the place of corporate worship and mass initiation at the Lateran becomes the exclusive domain of the emperor at Blachernae, where the ceremonies of the imperial cult become embodiments of divine agency. If a tentative parallel is drawn between $C$ hristian baptism and imperial ablution then the complex of buildings at Blachernae, that comprise palace, basilica, reliquary chapel, sacred spring and so-called "bathhouse", could be described as being a Byzantine "version" of the church complex of the Lateran, with its similar arrangement of palace, basilica, chapel of the Holy Cross, baptistery and monumental fountain courtyard. ${ }^{27}$

O ttoman Turks. Constantine XI, the last Byzantine emperor, is said to have spent his last days at the imperial palace at Blachernae before joining his army to fight Sultan M ehmed II in 1453 .

26. This is highlighted in an early $6^{\text {th }}$ century ceremony that took place each Friday and entailed a procession from Blachernae to the Church of the $\mathrm{C}$ halkoprateia, near $\mathrm{H}$ agia Sophia. See R. Janin, Les égli ses orientales et les rites orientales, Paris, Imprimerie P. Feronvrau, I926, p. I77.

27. The use of the term palatium to describe the Lateran complex in Early Christianity derives from the imperial residence on the Palatine, from whence "palatium" originated. The legacy of this imperial terminology and its associations were re-invoked at Blachernae, only here the liturgy and symbolism of the C hurch were more systematically integrated with the traditions and practices of the imperial cult, to the extent that both were indistinguishable. To this extent, the ritual ablutions at the "bathhouse" could be interpreted as an imperial "type" of Christian baptism. 
14

Whilst such direct comparisons can be overly simplistic they bring into focus the question of association. Indeed, allusions to Constantinople as $2^{\text {nd }}$ Rome, however open to interpretation, must always be understood in comparison with that other model, Troy. In keeping with Augustan practice, allusions to Constantinople as Troy revived further legitimized the founding of a new imperial capital. This second association, however, was somehow pre-ordained by the fact that Constantine had initially ear-marked the supposed site of Troy for his new capital. ${ }^{28} \mathrm{Clearly}$, the unique political and religious situation of Byzantium enabled a dialogue to be forged between Greco-Roman originary myth and imperial Christian practice. In this relationship the emperor became the effective embodiment of the Church and the church/palace model took on a particular symbolic role rooted in the Roman imperial cult. From a place of corporate participation and initiation at the Lateran, in which ritual and ceremony were administered and overseen by the bishop, the church/palace model was transformed in the Byzantine court into a setting that was specific to the actions of the emperor. Among the imperial rituals that took place at Blachernae were the following; the banquet, a traditionally religious affair between emperor, his court and the divine; the ritual ablution with its allusions to baptism, and finally the preEucharistic rite of the offertory, a liturgical oblation that, unlike in the West, was reserved exclusively for the emperor in the Eastern Church. ${ }^{29}$ Byzantine imperial statecraft provided a wholly integrated body of rituals that required the presence and participation of the emperor.

Implicit in the relationship between imperial and $M$ arian cults in Byzantium was the notion of emperor as "perpetual triumphator" the efficacy of

28. The conflation of Christian tradition, Imperial Roman symbolism and Trojan myth is best observed in the so-called Burnt Column. Erected by Constantine to cel ebrate the dedication of Constantinople as new imperial capital, the column was originally supported on a vaulted and arched tetrapylon that was used as a sanctuary to celebrate $M$ ass. Beneath this was buried the original Palladium of Troy which Constantine had moved from Rome. Crowning the column was a bronze statue of Constantine which was an adaptation of an earlier statue of H elios. The emperor's left hand held a lance while his right hand held a globe, symbols of imperial authority. See Edwin Freshfield, A Letter to The Right H onourable Lord Aldenham, London, I900.

29. For a discussion of the offertory, see von Simson, pp. 29-30.

30. Indeed, it was believed that the Virgin, rather than the emperor, had put an end to the $7^{\text {th }}$ century siege of C onstantinople and ensured victory over the Persians, Slavs and Avars. As 
which could only be guaranteed by the spiritual presence of the Virgin. The divine power of Theotokos gave the Virgin a role of "command" in times of conflict. ${ }^{30}$ From this symbolism it would seem that the cyclic ritual in the polygonal structure at Blachernae, in which the nuptial waters poured from the breasts of Theotokos, was intended to call upon the spiritual fecundity of the Virgin as an agent of renewal of empire., ${ }^{31} \mathrm{H}$ ence, the emperor, in his "burial" and spiritual cleansing in the consecrated water, served as a mediator in this replenishment of empire.

The idea of emulating the symbolism of the redeemed and resurrected neophyte in this ceremony of imperial renewal brings into focus two important characteristics. On the one hand it demonstrates an enduring belief in the providential nature of emperor that was to permeate Christian imperial ceremonial. $O \mathrm{n}$ the other hand, it re-affirms the faith in the efficacy of baptismal symbolism, or at least a version of it, in ensuring spiritual rebirth.

As suggested earlier, in relation to the 0 rthodox Baptistery at Ravenna, the symbolism of the throne is key to an understanding of the relation between imperium and sacerdotium in Early Christianity. By the late $5^{\text {th }}$ century there developed widely differing views about the nature and meaning of the imperial throne between east and west that centered on the contention

bearer of the Godhead, $M$ ary emanated a numinous presence that helped sustain and protect imperial rule.

3I. It may even be the case that the sanctity of the spring at Blachernae derived from an earlier pagan cult that was adapted in Early Christianity.

32. An inference of this relationship between east and west, albeit of a later period, can be seen in an intriguing account of an ambassadorial mission to Constantinople, the Relatio de L egatione Constantinopolitana, by the Io $^{\text {th }}$ century Bishop of Cremona, Liudprand. Summoned by $\mathrm{O}$ tto I (936-973) to travel to the eastern empire as a representative of the Lombard court to meet the Byzantine emperor, $\mathrm{N}$ icephorus, Liudprand provides a fascinating, if biased, account of his experiences. H e describes his poor treatment by court officials and condemns many aspects of court ritual in Constantinople (Liudprand of Cremona, in Brian Scott (ed.), Relatio de Legatione Constantinopolitana, London, Bristol Classical Press, 1993, p. 65). $\mathrm{H}$ e describes the acclamations that the Byzantine emperor received when solemnly processing to the holy sites in Constantinople, that probably included Blachernae. As an integral part of Byzantine court ceremonial, with clear liturgical overtones, these ceremonies were described by Liudprand in somewhat snide terms, reflecting a skepticism about their symbolic significance. Underlying this skepticism is a conflict between Pope John, "his beloved spiritual son" $\mathrm{O}$ tto I and $\mathrm{N}$ icephorus. In a letter sent to the Byzantine emperor by the pope, $\mathrm{O}$ tto I is described as the "august emperor of the Romans" whilst $\mathrm{N}$ icephorus is called "emperor of the 
DOI: http://dx.doi.org/10.22201/iie.18703062e.2002.80.2105

16

NICHOLAS TEMPLE

of the sovereign role of the pope as final judge of the legitimacy of imperial rule. The source however of this emerging schism can be traced back to Constantine himself, as will be explained later. ${ }^{32}$

\section{Baptism and Topography}

The conflict between the institutional integration of imperium and sacerdotium in the Eastern empire and their effective separation in the West is clearly not what Constantine had intended in his project of Christianization. Put in context, the evident dichotomy between the first Christian emperor's high ambitions, to create a single unified Christian empire, and the reality of unresolved initiatives and isolated successes, was probably the main reason for relocating the imperial seat to Byzantium. In spite of Constantine's largely failed enterprise to tranfform Rome into a Christian imperial city, the emperor recognized the critical role of baptism in uniting church and state. As a symbolic and ritual threshold between an old and "defunct" pagan past and an anticipatory future of redemption, baptism acquired as much a political as a religious purpose in Early Christian Rome. This, it seems, made it particularly receptive to re-interpretation in the later Byzantine court, highlighted earlier, as a specifically imperial ritual for affirming the renewal of empire.

It is possible to draw parallels between the underlying political intentions

Greeks" (op. cit., p. 47). N icephorus condemns his title and Liudprand, following his summoning to the palace, becomes embroiled in a dispute with the "Patrician Christopher," a eunuch. The patrician informs Liudprand that Constantine transferred the imperial scepter, along with the Roman senate, to the new capital and therefore $\mathrm{N}$ icephorous, as inheritor of the imperial throne, is the legitimate Roman emperor. Liudprand reminds the patrician that Constantine came from a Roman army and since the Byzantine court changed the language, customs and dress, "H is H oliness [Pope John] assumed that the name of Romans appealed as little to you as the Roman mode of dress" (ibid., p. 5I). A dispute develops between pope and Byzantine emperor that centers around the status of the imperial throne. Luidprand asserts that $\mathrm{N}$ icephorus had obtained the throne through perjury and adultery. $\mathrm{H}$ e uses this claim of usurpation, and its defiling effects on the larger empire, as a rhetorical weapon to demote the sacred meaning of the Byzantine throne: "Since the pope is concerned with the spiritual welfare of all Christians, let the lord pope send $\mathrm{N}$ icephorous a letter like sepulchers, all white outside, but full of dead bones within. In it let him castigate $\mathrm{N}$ icephorous for having seized the throne... Let the pope invite him to a synod, and if he refuses to come, excommunicate him" (ibid., p. 52). 
of the baptismal rite under Constantine, as a redemptive passage to a Christian life, and the understanding of the topography of Rome as a political construct that differentiates between Christian and pagan traditions. A catalyst to this view of topography was Constantine's refusal as "perpetual triumphator" to offer sacrifice to Jupiter O ptimus M aximus on the Capitol that in turn challenged the meaning of romanitas. Critical to Constantine's departure from imperial practice was the traditional notion of the $C$ apitol as an embodiment of empire. The demise of the ritual of sacrifice at the main state shrine, traditionally the culminating event of the Roman triumph, could be said to anticipate the decentralization, and ultimate dismantling, of the hierarchical structure of Roman religion. This was initially undertaken by shifting the focus of religious activity from the $\mathrm{C}$ apitol, the de facto center of Empire, to the peripheral territories of the city, in the venerated burial sites of the C hristian martyrs.

$\mathrm{H}$ istorically, religious practice in primitive $\mathrm{Christianity} \mathrm{took} \mathrm{place} \mathrm{in} \mathrm{the}$ virtual seclusion of domestic buildings, or domus ecclesiae, that were located in urban centers. The inconspicuousness of these humble buildings in the larger urban topography of imperial Rome provided safe refuge during times of persecution. It is significant that Constantine chose not to develop these, or other related sites, for public worship in the central area of Rome, but instead instigated the construction of monumental basilicas extra muros. As Richard Krautheimer emphasizes:

The sanctuaries outside the walls at the graves of the martyrs and of Saint Peter could not hurt anybody's feelings. N or could $\mathrm{S}$. Croce, hidden inside the Sessorian Palace, possibly offend the susceptibilities of even the most fervent upholder of the old faith. O nly the cathedral at the Lateran rose in the open, as it were inside the city walls. Still, like S. C roce, it remained outside the pomoerium, the religious boundary marked by the old Republican, the so-called Servian Wall, and still respected after the building much further out of the Aurelian W alls. W here the Lateran cathedral rose, half an hour's walk or more from the sensitive area in the city's center with its pagan overtones, it would at least not blatantly insult conservative pagan feeling. ${ }^{33}$ 


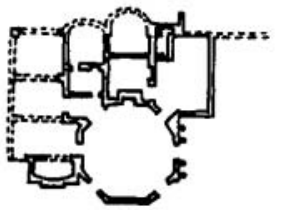

Baptistery

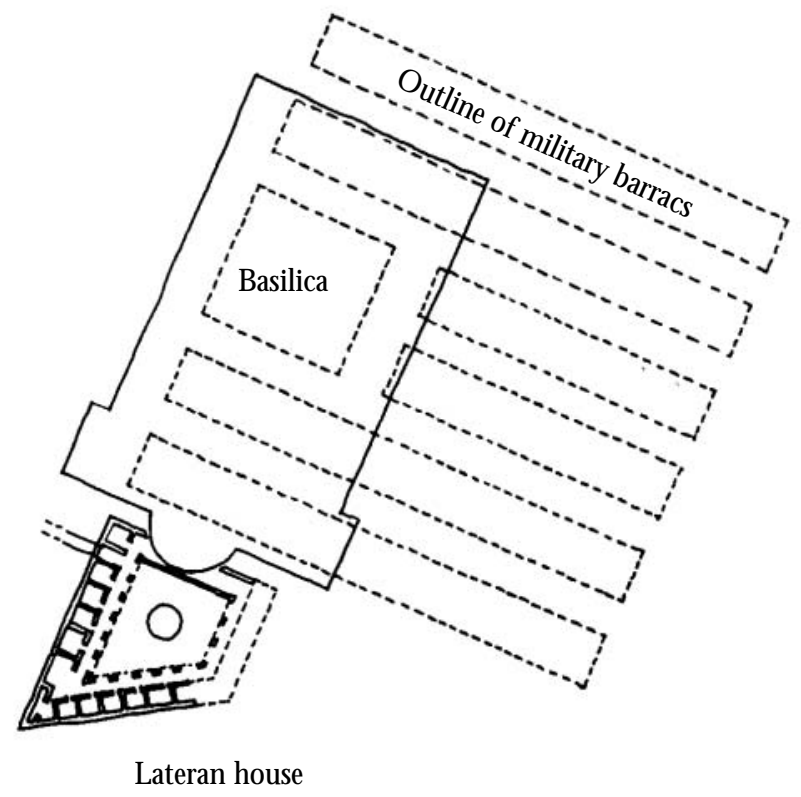

I. Layout of the Lateran Complex ( $4^{\text {th }}$ century) highlighting the incorporation of the Constantinian baptistery in the Severan domestic bath building. Based on G. Pellicioni's reconstruction (1973) and drawn by author.

W hilst the construction of these venerated shrines on the sites of Christian cemeteries and catacombs extra muros was in keeping with Roman burial custom, the absence of places of congregation in the central area of the city, on those sites formally occupied by Christian dwellings, suggests a different understanding of the relation between religious participation and urban life when compared to pre-Constantinian times. Indeed, the location of these new basilicas lay outside the very domain where $C$ hristian worship had first

34. Curran, Pagan City and Christian Capital, p. 7I. Besides Krautheimer, Curran also refers to Pietri and Alfoldi as supporters of this theory which he challenges. In particular, Krautheimer states: "Keeping his first church foundation and indeed all later ones as far as possible from the center of Rome, because of the predominance of conservative and religiously traditional groups both in the Senate and among the population, was by necessity, in 313-13 certainly, but for some years to come as well, an integral part of Constantine's building policy." K rautheimer, ThreeChristian Capitals, pp. 28-29. 


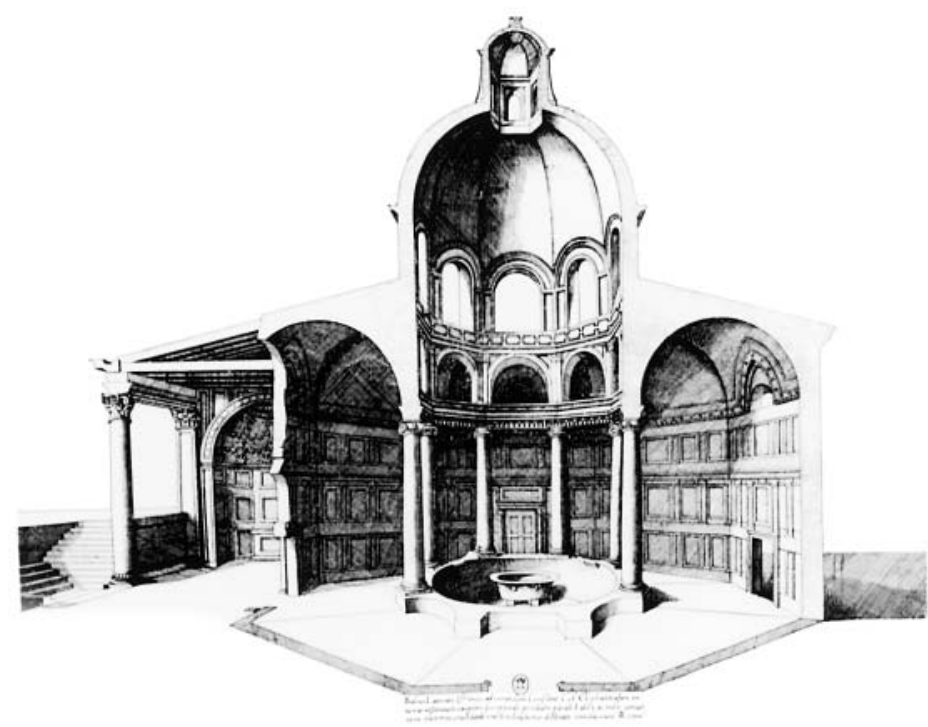

2. Sectional reconstruction of the Lateran Baptistery during the period of Pope Sixtus III (432-440); ca. 1560 engraving by A. Lafrery (from P. Lauer, Le palais de Latran, Paris, I9II, Library of the British School at Rome).

taken root within the city. Krautheimer's claim, however, of political sensitivity towards the presence of Christian buildings in the old religious center of pagan Rome is criticized by John Curran who considers this as a misinterpretation of the real intentions of Constantine.34 Timidity, Curran argues, was not a characteristic of the new emperor, and however Constantine balanced political expediency with the need to re-assert his own authority it can be argued that the changes imposed by the emperor were underpinned by a clear political objective.

Precisely what this objective was can partly be ascertained by the political nature of conversion. O nce celebrated in the company of a small congregation in Primitive Christianity, baptism under Constantine took on a public dimension that was administered at the edge of the city, as it would have been perceived in Late Antiquity, in the Lateran complex and elsewhere in the suburban periphery. This shift from center to periphery only served to underline the territorial distinction between Constantine's vision of a new Christian empire, as embodied in the venerated sites of martyrs and the Lat- 
eran complex, and the still relevant but nevertheless declining traditions of the old pagan city.

Closely allied to Constantine's self-declared role as emissary of Christ was his imperial status as perpetual triumphator. In this role, the question of continuity with the pagan past was intentionally disrupted by Constantine, and yet the symbolism of triumphalism was not erased or forgotten. Instead, it was appropriated by means of a particular eschatological understanding of imperium, in which Constantine is portrayed as the agent of a new beginning. This, I would argue, is particularly pertinent to our understanding of baptism at this time as part of a process of conversion to an altered worldview. $O$ ne aspect of this transformation from a pagan to a $C$ hristian imperial tradition, that is especially relevant to conversion, concerns the relation between mortuary and triumphal symbolism. This is suggested in a Latin inscription found in the Constantinian Basilica of St. Peter's in I506. Located on the triumphal arch of the old Basilica, which divides the transept from the nave, the epigraph reads as follows in translation: "Because under Your [Christ's] leadership the world rose triumphant to the skies, Constantine, himself victorious, has founded this hall in Your honour". ${ }^{35}$ The epigraph was accompanied by a mosaic, probably of slightly later date, which apparently depicted Constantine presenting a model of the basilica to Christ and Peter. As John Curran highlights, what is emphasized in the encomium is Constantine's military successes rather than his role as builder. 0 ne implication of this conflation of Christian mortuary and imperial military symbolism is that the triumphal arch of St. Peter's Basilica, that symbolized Christ's eternal victory over death, functioned as a kind of sacred counterpart to the Arch of Constantine near the Colosseum that commemorated the Christian emperor as the victorious hero and temporal ruler.

O ne implication of this topographical interpretation of Early Christian imperial symbolism is the possibility that the mons Vaticanus was construed by court panegyrists, and perhaps by Constantine himself, as a C hristian version of the Capitol. Whilst there is no evidence to prove such a relation there is, I believe, reason to speculate on this idea. The Vatican had a special topo-

35. Q uoted in Curran, Pagan City and Christian Capital, p. II2.

36. M argherita Guarducci, Pietro in Vaticano, Rome, Libreria della Stato, 1984; for a general discussion of the Roman Triumph see H.S. Versnel, Triumphus. An Enquiry into the O rigin, D evelopment and $M$ eaning of the Roman T riumph, Leiden, E. J. Brill, 1970. 
graphical and ritual relationship to the Capitol. U sed as the marshalling ground for armies returning to Rome after battle, the Vatican fields provided a staging post for the ceremony of the Roman triumph at the gateway to the Campus $M$ artius, along the via triumphalis and pons Triumphalis. This procession culminated in the sacrifice to Jupiter on the Capitol..$^{66}$ It is unlikely that this important military function of the Vatican went un-noticed by C onstantine when he inaugurated the building of St. Peter's Basilica. Indeed, it seems plausible that the memory of the Roman triumph was consciously invoked in the Constantinian inscription in St. Peter's Basilica, in the sense that martial triumph was re-appropriated as the triumph over death of St. Peter following his martyrdom. The refusal by the Christian emperor to sacrifice to Jupiter meant, in one sense, that the venerated temple on the Capitol could no longer serve as the symbolic fulcrum of empire. Under Constantine's successors this status was passed on to the shrine of Peter, most venerated of the Apostles and key-bearer of the C hurch. ${ }^{37}$

The $C$ hristianization of the Vatican was aided by an important natural feature of the site, an underground spring. This was to have a direct bearing on the symbolism of the Vatican baptistery that was constructed in the Constantinian Basilica by Pope D amasus in the late $4^{\text {th }}$ century. The spring supplied water to the font that was located in the south transept of the Basilica, within

37. Evidence of the legacy of the Vatican as territorium triumphalis can be seen in the use of the term "trofeo" for Peter's burial-place during the early M iddle Ages. M ore commonly denoting monuments commemorating the scenes of battle in Roman and $G$ reek antiquity, the trofeo was typically a circular mounded structure surmounted by trophies of war. The ancient Roman practice of interring the body of a dead soldier or hero within these mounds may have provided further justification for the term trofeo being applied to the Petrine shrine, the burial site of the venerated saint. M argharita Guarducci, "I Trofei degli A postoli Pietro e Paolom," in Atti della Pontificia Accademia Romana di Archeologia - Rendiconti, Serie III (1984), vol. LII-LIV, p. I36.

38. The Vatican Baptistery was constructed as part of an operation to drain the $\mathrm{V}$ atican $\mathrm{H}$ ill under Pope $D$ amasus.

39. "T he quarter on the right bank took Peter into its charge and keeps him in a golden dwelling [basilica], where there is the grey of olive-trees and the sound of a stream; for water rising from the brow of a rock [mons $V$ aticanus] has revealed a perennial spring which makes them fruitful in the holy oil. N ow it runs over costly marbles, gliding smoothly down the slope till it billows in a green basin [cantharus]. There is an inner part of the memorial where the stream falls with a loud sound and rolls along in a deep, cool pool [baptistery]. Painted in diverse hues colours the glassy waves from above, so that mosses seem to glisten and the gold is tinged with green, while the water turns dark blue where it takes on the semblance of the 


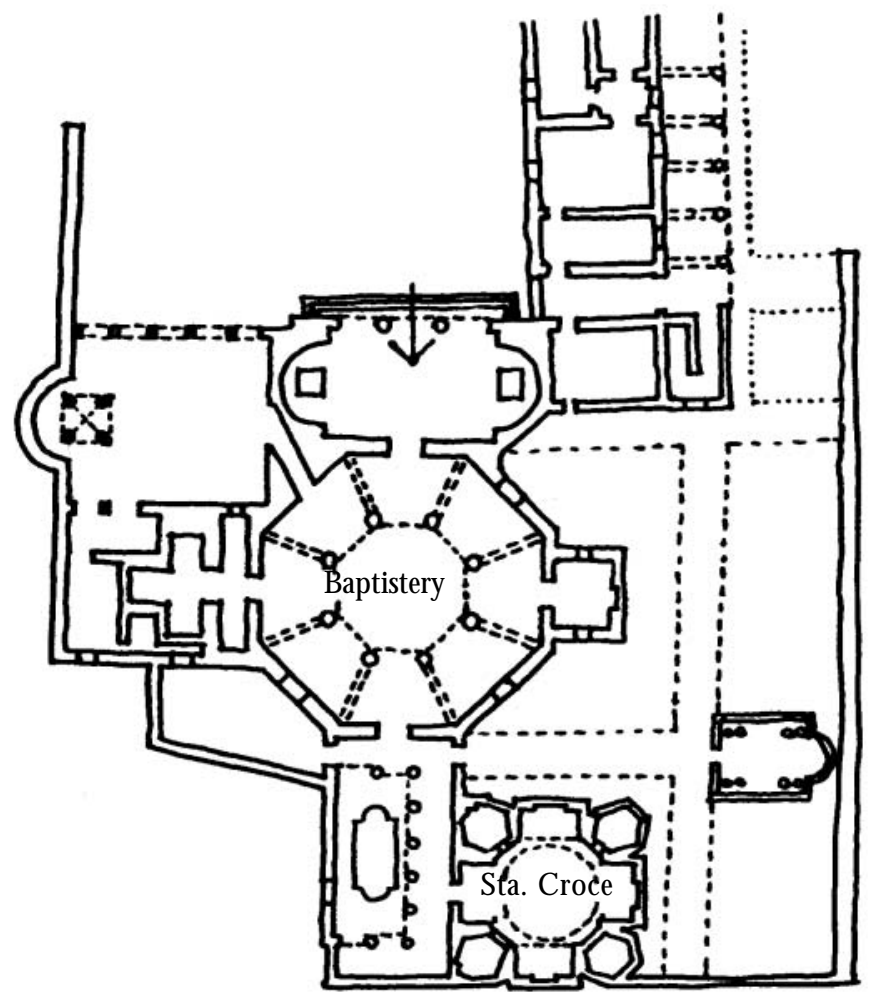

3. Plan of the Lateran Baptistery and Sta. Croce (C onsignatorium) during the period of Pope H ilarius (46I-468); based on reconstruction by G. G iovenale (1930) and drawn by author.

visible range of the burial place of St. Peter. $3^{8}$ In a description of the baptistery by the $4^{\text {th }}$ century commentator Prudentius the spring is conveyed poetically as the source of sanctified water, whose symbolism may be attributed to the fact that its course came in close proximity to the burial site of St. Peter. 39 In

overhanging purple, and one would think the ceiling was dancing on the waves. There the shepherd himself nurtures his sheep with the ice-cold water of the pool, for he sees them thirsting for the rivers of Christ." Prudentius, trans. $\mathrm{H}$.J. Thomson, Loeb Classical Library, Cambridge, M ass., H arvard U niversity Press, 1949, pp. 325-27.

40. For many, to be baptized in the water sanctified by Peter's body provided some com- 


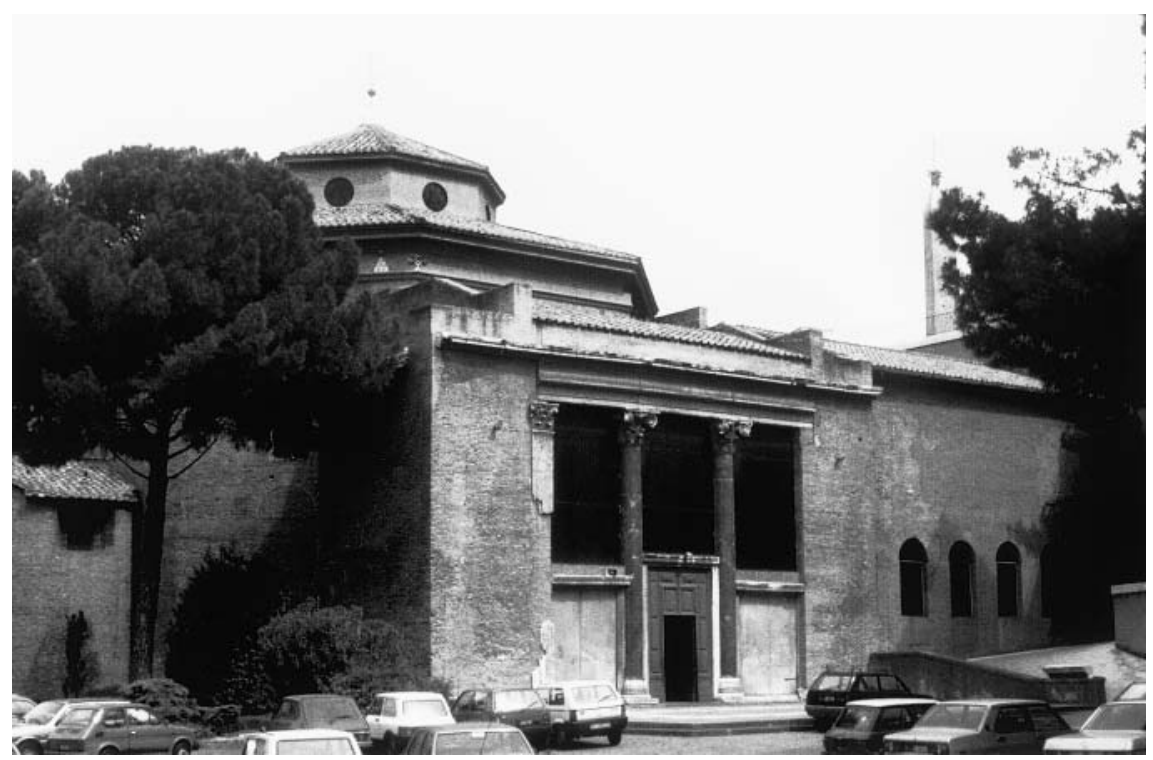

4. View of the Lateran Baptistery today, looking towards the original entrance (portico 'a forcipe'). Photo by author.

other words, the significance of the spring as a source of spiritual plenitude was probably based on the belief that the water was consecrated by the remains of St. Peter. This mortuary significance is consistent with representations of the four rivers of Paradise in Early Christian and M edieval mosaics that typically show water pouring from the base of the sacrificial cross. ${ }^{40}$

Prudentius' description of water flowing over "costly marbles" and into a "green basin" is most likely a reference to the famous cantharus, a famous bronze fountain that was located in the atrium of the Basilica. ${ }^{4 \mathrm{I}} \mathrm{T}$ he description implies that the spring supplied water to the fountain. With its assortment of motifs symbolizing rebirth and fecundity, most importantly a large central pine cone and elaborate bronze peacocks positioned at the corners of

pensation for being denied a burial site in the cemetery that once surrounded the venerated grave of the Apostle, following the construction of the Constantinian Basilica.

4I. See note 38 . 
an overhead canopy, this monumental fountain would have been understood by many as an appropriate symbolic prelude to the place of baptism.

It is in the context of this efficacy of the sanctified waters of the spring that the memory of the Vatican as territorium triumphalis becomes especially significant. Prior to entering Rome and becoming re-integrated into the life of the city, the victorious armies of antiquity were required to undergo various cathartic rituals to eradicate the deleterious effects of miasma, or stain, brought about by military combat. ${ }^{2}$ The Vatican probably provided the first location for these rituals, prior to crossing the pons Triumphalis to the Campus $M$ artius. No doubt the memory of this triumphal and martial symbolism of the Vatican was still very much alive during the period of Prudentius. ${ }^{43}$

W hat emerges from this initial examination of imperial themes in Early Christian iconography and topography is the sense that the traditions and practices of Roman paganism were drawn into a dynamic relationship with the Christian world. ${ }^{44} \mathrm{D}$ uring the period of Constantine a complex relationship developed between prevailing Roman religious traditions and a new imperial Christian order. Both found expression in the religious life of the individual citizen and in the convivial ceremonies of the emperor. These in turn gave added impetus to the metaphorical understanding of baptism as a critical threshold between this life and the next.

\section{Constantine and Baptism}

As the site of the first baptistery constructed under Constantine, the Lateran was also the location of the first Constantinian basilica. It was here on the

42. See Versnel, op. cit., and A. Plattus, "Passages into the C ity: The Interpretive Function of the Roman Triumph," Princeton J ournal, I (1983), pp. 93-II5.

43. Prudentius' writings predate the disastrous Sack of Rome under Alaric in 4 Io when the Goths crossed the T iber river from the $V$ atican, probably across the still standing Ponte T riumphalis (or Pons N eronianus) and the Pons Aelius (Ponte Sant'Angelo). It is likely that this legacy provided one of a number of symbolic references in the poet's evocation of the unique redeeming and cathartic effects of Peter's martyrdom as a spiritual triumph over death.

44. The deliberate subservience of one history by another in Constantine's political and religious enterprises would ultimately lead to the pagan world being expunged altogether as a lived experience. This took place under Theodosius I in the late $4^{\text {th }}$ century when pagan worship was prohibited and temples were either closed, adapted to C hristian use or destroyed. 
C elian $\mathrm{Hill}$, in the eastern part of Rome, that we witness the beginnings of a formulation of ritual practice and iconography that was to become prototypical of later ecclesiastical complexes in Italy. The choice of this site for the first Christian basilica, St. John the Lateran, and adjacent baptistery raises many questions about Constantine's political and religious intentions. It is not without significance that the first $C$ hristian emperor chose a location that was formally the site of the barracks of the horse guard of $M$ axentius, the Castra nova equitum singularium. ${ }^{45}$ It seems plausible that the location of the complex of buildings in the Lateran, on the edge of Rome, was intended to be seen as much a political as a religious statement in Constantine's program of conversion. Initiation and participation in the Church acquired particular topographical and spatial meanings that were consciously distinguished from those of the old pagan city. Implicated in this, as I have already argued, is the idea of two "cities", one pagan and the other Christian,

45. The demolition of this complex of buildings, to make way for the new religious complex of $C$ hristianity, probably formed part of a larger initiative to erase all vestiges of $M$ axentius's rule in Rome, following his defeat at the hands of Constantine at the battle of Ponte $M$ ilvio. Indeed, many of the projects that $M$ axentius had initiated in and around the city were altered under Constantine in an attempt to expunge any association with his predecessor. Constantine portrayed M aximus as the "Syrian" tyrant, whilst he portrayed himself as liberator. Curran, Pagan City and the Christian Capital, pp. 76-77.

46. The former is centered on the old city, as defined by the religious and political institutions, whilst the latter is located as a peripheral zone outside the Aurelian wall. The ritual meaning of baptism, as a symbolic gateway to the new Christian empire, resonates topographically by the fact that the Baptistery of the Lateran, like the Basilica, is located close to the Porta Asinaria, one of the principal city gates through the Aurelian wall which was later used by pilgrims to access the burial sites of the martyrs fuori le mura.

47. Expropriated by $\mathrm{N}$ ero from the Lateran family in the first century $\mathrm{AD}$, the land on which Constantine later built the complex of buildings contained an existing Roman house and domestic thermal building, both thought to date from the Severan period. The unification of these properties in the early $4^{\text {th }}$ century into a single habitation may have formed the D omus Faustina, the house of $M$ axentius's daughter and later wife of Constantine. Filippo Coarelli, G uide archeologiche Laterza: Roma, Rome, Gius, Laterza \& Figli Spa, 1985, p. I73.

48. The decision to adapt the earlier bath building for a baptistery was partly, it seems, to utilize the existing water supply from the nearby Aqua Claudia that fed the frigidarium. The archaeological findings of the two circular structures were published by G. Pelliccioni, Le N uove Scoperte sulle O rigini de Battistero Lateranence, Atti Pontificia Accademia M emorie, xiI, Vatican City, 1973, p. 84, n. 2. Krautheimer, however, questions whether a second circular structure was built; Early Christian and Byzantine Architecture, p. 495, n. 47. In any case it is 


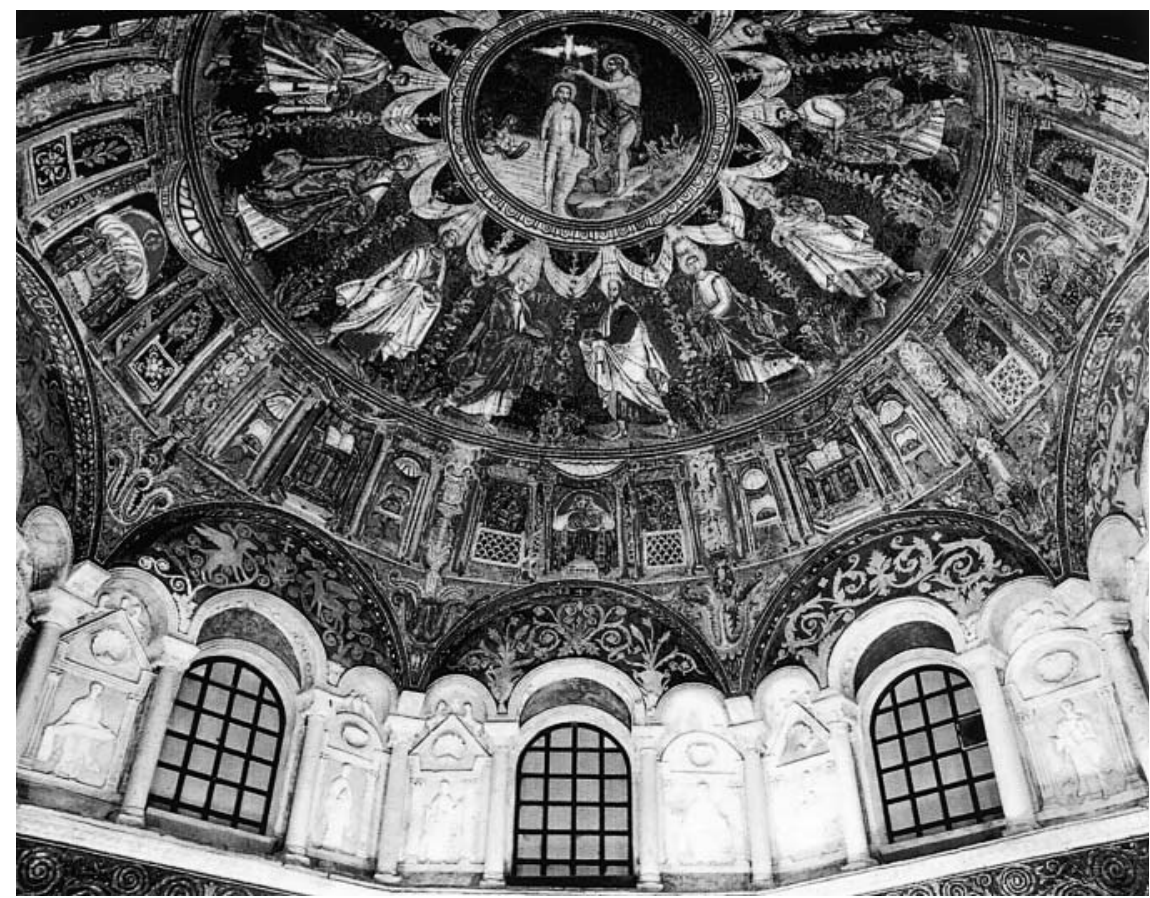

5. View of the mosaics of the dome of the 0 rthodox Baptistery in Ravenna (from $5^{\text {th }}$ century). $\mathrm{N}$ ote the alternating representations of altars and vacant thrones in the lower band.

that could be said to anticipate St. Augustine's twofold theological model of civitas dei and civitas terrena. ${ }^{46}$ Archaeological excavations in this area have revealed a complex stratification, reflecting numerous interventions, alterations and reconstructions.47 Prior to AD 312, a circular structure was inserted into the existing thermal building, the function of which is uncertain. $4^{8}$ 0 ver this, a second circular structure was built, allegedly Constantine's baptistery, whose font was largely an adaptation of an earlier pool in the frigi-

possible that this first structure may have been used as a baptistery in the existing Domus before C onstantine.

49. L. D uchesne, Le Liber Pontificalis, vol. I, Paris, I88I-I892, p. 234. The function of these columns was presumably to provide added structural support for a domical roof, the construction of which remains unclear. 


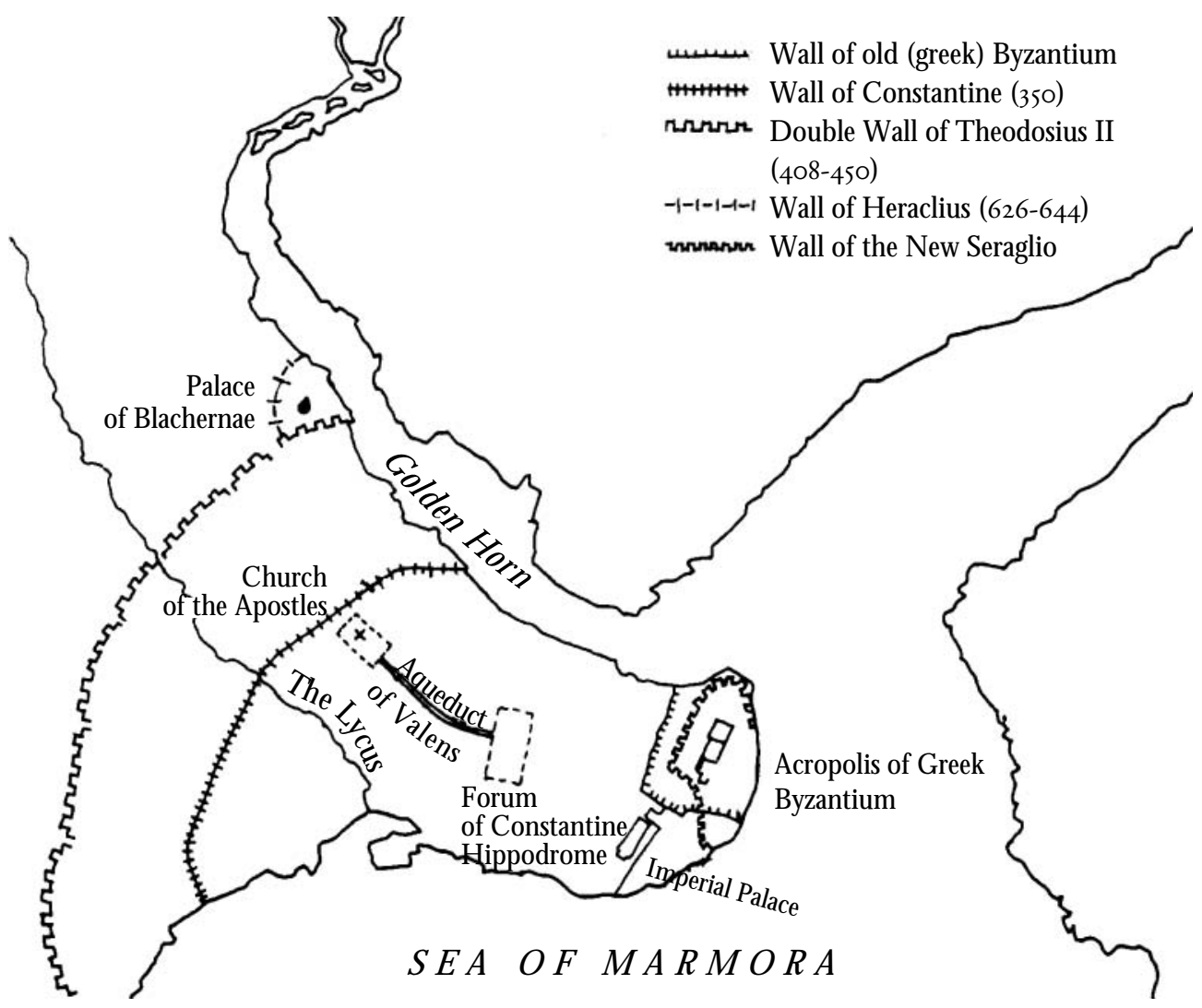

6. O utline map of Constantinople showing location of the Palace complex of Blachernae, to the north of the ancient city near the $\mathrm{G}$ olden $\mathrm{H}$ orn, indicating extension of the earlier $5^{\text {th }}$ century city wall around the venerated site by H eraclius (626-64I); based on map by William Shepherd (1923) and drawn by author.

darium of the thermal building. Under Constantine this circular building was replaced by an octagonal structure, whose inner angles accommodated columns donated by the emperor to the Church. ${ }^{49}$

The reason for changing the shape of the new Constantinian building, from a circular to a larger octagonal structure, is generally attributed to practical requirements, to provide more space for baptizing increasing numbers 
DOI: http://dx.doi.org/10.22201/iie.18703062e.2002.80.2105

of catechumens. It is likely, however, that the symbolic associations of the octagonal form were germane to this change even though the specifically Christological meanings of the octagon were not formulated until the late $4^{\text {th }}$ century by St. Ambrose. Before then, it is conceivable that the octagon was more generally associated with divine harmony, as defined in the mystical octave. O ne ancient literary source that may have informed this symbolism can be found in Plutarch's "Life of Theseus" where the number eight is associated with hero ruler-ship..$^{\circ 0}$ The question of whether the symbolism of eight taken from Plutarch was consciously adopted in the iconography of the Constantinian baptistery is open to speculation. M ore probably, it formed

50. "T he chief and most solemn sacrifice which they celebrate to him [T heseus] is kept on the eighth day of the Pyanepsion, on which he returned with the Athenian young men from Crete. Besides which, they sacrifice to him on the eighth day of every month of $\mathrm{H}$ ecatombaeon, as D iodorus the geographer writes, or else thinking that number to be proper to him, because he was reputed to be born of $\mathrm{N}$ eptune, because they sacrifice to $\mathrm{N}$ eptune on the eighth day of every month. The number eight being the first cube of an even number, and the double of the first square, seemed to be an emblem of the steadfast and immovable power of this god, who from thence has the names of Asphalius and G aeiochus, that is, the establisher and the stayer of the earth." Plutarch's Lives of Illustrious M en, trans. John D ryden, revised by Arthur $\mathrm{H}$ ugh Clough, Philadelphia, John C. W inston, 1908, pp. 34-35. In this description Plutarch attributes a special significance to the number eight, as it relates to the "eighth day of the Pyanepsion," the harvest festival of A pollo. Being the day on which Theseus was celebrated annually in ancient G reece it carried a particularly auspicious meaning. The "Asphalius," furthermore, was a surname given to Poseidon, Greek god of the sea and of earthquakes who, according to some claims, was actually Theseus' father. The 0 xford Classical D ictionary, Simon Hornblower \& Antony Spawforth (eds.), Oxford, Oxford U niversity Press, 1996, p. 1508. "Asphalius" also attributes the deity to granting safety to ports and to navigation. At the same time, from epithets by Pausanias, "A phaleios" is described as "H e who keeps things steady," which is similar to the meaning of Poseidon's other name, "Gaeiochus," the holder or stayer of the earth. The significance of these terms in the context of the symbolism of eight is highlighted by Plutarch's typically Pythagorean interpretation of the number as being the "first cube of an even number [ $\left.{ }_{2 \times 2} \times 2\right]$, and the double of the first square $[4+4] \ldots$.. $H$ is assertion that this number is an "emblem of the steadfast and immovable power of the god" is underlined by the fact that the attributions of the deity relate both to water and to earth, the two elements pertaining to the chthonic real $\mathrm{m}$. In this sense, the octagon could be understood as a mediator between square and circle, between the terrestrial and the celestial/chthonic. The status of circle and square in these symbolic terms is briefly highlighted by Varro in the context of an aviary; D e re rustica, bk. 3 .

51. Association of this symbolism with imperium typically finds expression in imperial reception halls and throne rooms such as the famous hall of N ero's D omus Aurea and the 


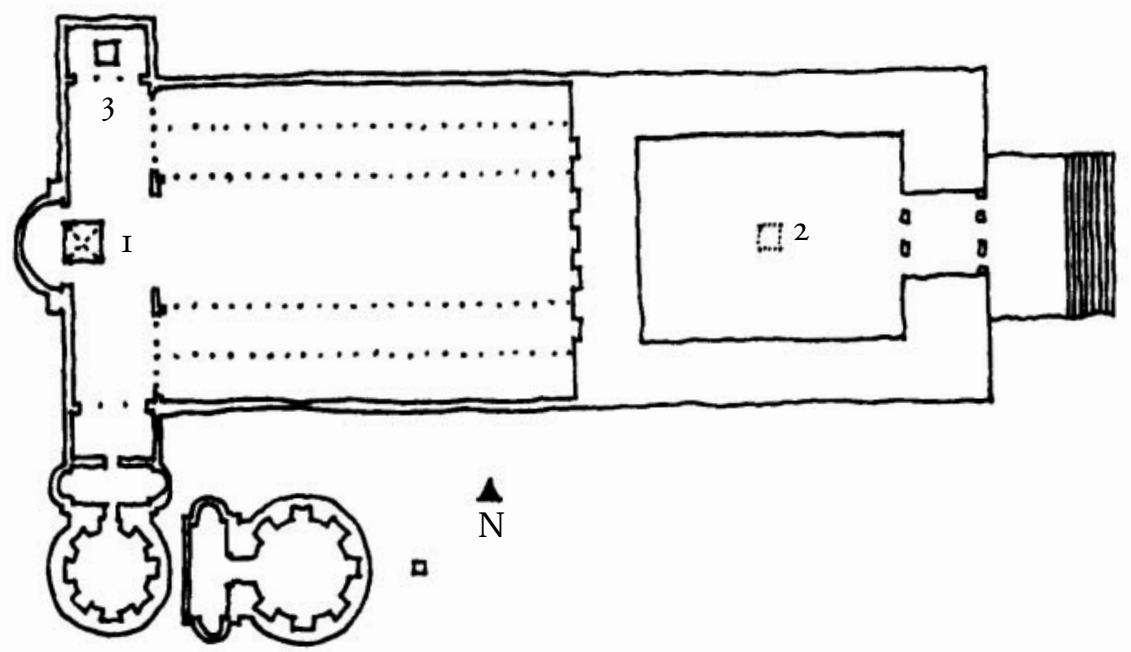

7. Plan of the Constantinian Basilica of St. Peter indicating location of the shrine of St. Peter (I), the so-called 'pine-cone' fountain (2) and the later $4^{\text {th }}$ century baptistery $\left.{ }_{3}\right)$ installed in the $\mathrm{N}$ orth transept and described by the poet Prudentius (348-405).

part of a more generally received tradition that contributed to the symbolic understanding of the octagon in antiquity. . $^{\text {I }}$

The adoption therefore of the octagon at the Lateran may have been influenced by an essentially pre-Christian Platonic view of the octave as a symbol of cosmic harmony. It seems plausible, moreover, that the privileged

later domical octagonal space in the Flavian Palace (D omus Augustana). J.B. W ard-Perkins, Roman Imperial Architecture, H armondsworth, Penguin Books, I98I, pp. IOI-IO4. The association of the octagon with imperial symbolism continued during the reign of Constantine in the so-called "Golden O ctagon" in Antioch. Also called the "C hurch of Concord," the building was dedicated, according to Richard Krautheimer, to "... H armony, the divine power that unites U niverse, Church and Empire." Krautheimer, Early Christian and Byzantine Architecture, p. 8o. In all probability, it was used as the imperial chapel and possibly a throne room, since it adjoined the imperial palace, not dissimilar to the circular soros adjoining the imperial palace at Blachernae referred to earlier, that may have served as a private chapel for the emperor. It is likely that Constantine sought to emphasize in the Golden $O$ ctagon a continuity between certain aspects of pagan and Christian symbolism by utilizing many of the forms and ceremonial practices commonly associated with the traditional imperial reception hall. 
role of the emperor, in his ritual dialogue with divinity, was somehow equated with the catechumen undergoing baptism. O ne prominent feature of the Constantinian baptistery at the Lateran was the enormous font. Recessed into the ground by three steps, evocative of the trinity, the baptismal pool was the largest known and was designed specifically for mass baptisms. The size clearly indicates Constantine's ambition to convert as many people as possible, given the fact that the vast majority of Roman citizens were still pagan, and many suspicious of the new state religion. A low parapet, that accommodated eight shallow niches facing outwards, surrounded the font and were each aligned with the bays between wall-columns. It is likely that the recesses around the font where designed to hold precious furnishings, also donated by Constantine and recorded in the Liber Pontificalis.

Besides these donations, the emperor al so gave two censers, or thymiamateria, as gifts to the Lateran Baptistery.52 0 ne of these was positioned atop a porphyry column located in the middle of the giant font. The custom of ceremonial incense in Church liturgy is, as M assey Shepherd points out, commonly ascribed to St. Ambrose of M ilan although the evidence is not entirely clear. 53 Before then, the burning of incense in Roman practice was typically a ritual of homage to a venerated figure, especially an emperor. Censers were usually in the form of portable burners that were carried in a ceremony by officials of the imperial court. We know that, according to the Actus Silvestri, a ceremonial took place in which Constantine was returning from the Basilica U Ipia to the Lateran "Et revertente augusto ad palatium tota civitas replete cereis atque lampadibus coronata est." 54 W hilst the censer atop the column in the Baptistery was probably a permanent fixture, the other censer donated by Constantine may have been carried during pre or post-baptismal cere monies. Shepherd is probably right in pointing out that "the adoption by the churches of ceremonial customs associated with the imperial court cannot be attested before the reign of Theodosius I." N evertheless, it is reasonable to suppose that the association of censers with imperial rule did not suddenly disappear following Constantine's gifts to the Lateran..55 Rather, it is likely

52. Sible De Blaauw, Cultus et Décor: Liturgia e Architettura nella Roma Tardoantica e M edievale, V atican City, Biblioteca A postolica Vaticana, I994, p. I4I.

53. M assey $H$. Shepherd, Jr., "Liturgical Expressions of the Constantine T riumph," D umbarton Oaks Papers, 2I (1967), p. 62.

54. Q uoted in D e Blaauw, Cultus et D écor, p. I4I.

55. Shepherd, "Liturgical Expressions," p. 62. 


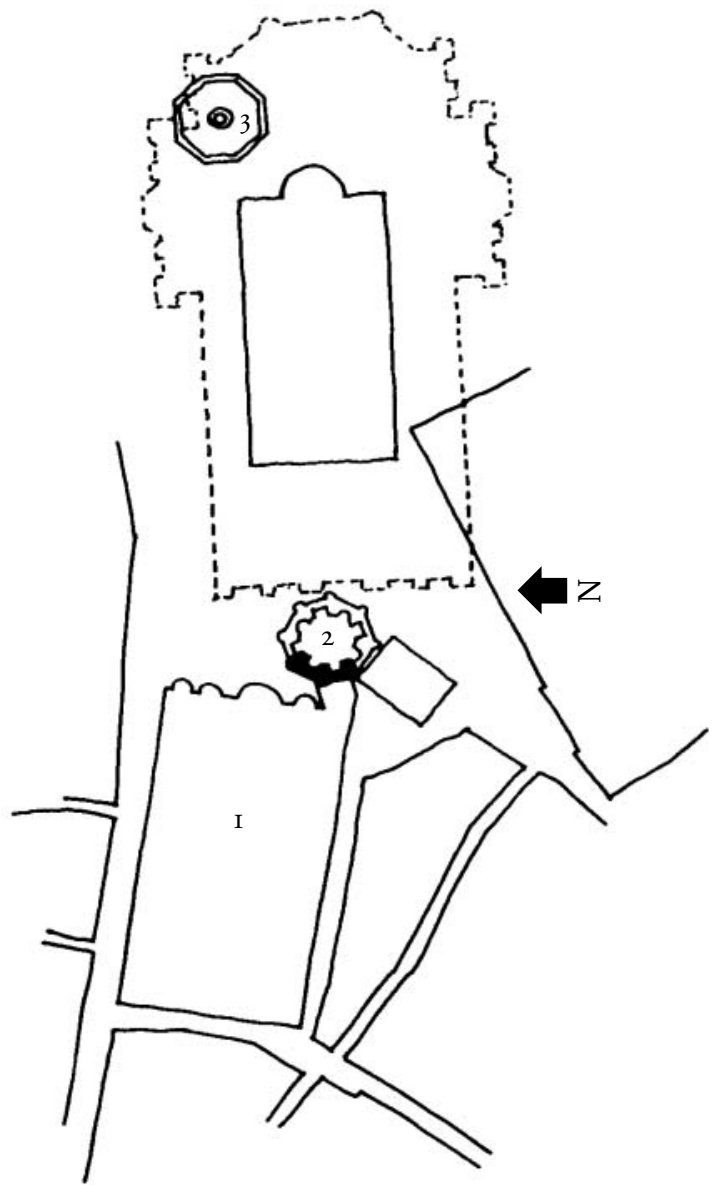

8. Plan of the basilica complex in early $5^{\text {th }}$ century M ilan, indicating Santa Tecla (I), the Ambrosian Baptistery (2) and the Baptistery of Santo Stefano (3), the reputed place of St. Augustine's baptism by Bishop Ambrose. The building shown dotted indicates the footprint of the later Gothic cathedral of $\mathrm{M}$ ilan; based on reconstruction by $\mathrm{M}$. M irabella (1969) and drawn by author. 
DOI: http://dx.doi.org/10.22201/iie.18703062e.2002.80.2105

32

NICHOLAS TEMPLE

that these ritual artifacts were intended to emphasize the presence of the emperor during the ministering of the holy sacraments by the bishop through the traditional associations of thymiataria with the imperial cult.

A clue to understanding the changing relation between ritual and architectural setting in the Lateran Baptistery can be found in the entrance sequence. From the investigations of $\mathrm{G}$. Pelliccioni it would appear that the present south entrance originally formed part of the $4^{\text {th }}$ century Constantinian pronaos "a forcipe". ${ }^{6}$ This consists of a narrow rectangular space running laterally across the south face of the baptistery and terminated at either end by apses. Similar entrance vestibules can be found in other domical buildings in Late Antiquity, such as the M ausoleum of Santa Costanza. M oreover, iconographic evidence, recorded in $16^{\text {th }}$ century drawings, of what were once $5^{\text {th }}$ century frescos in the narthex, along with extant mosaics in the vault in the east apsidiole, suggest that the narthex functioned as a consignatorium where the rite of confirmation was ministered by the bishop of Rome.57

56. Pelliccioni, Le N uove Scoperte... , p. 85. The expression "a forcipe" is used by Richard Krautheimer to denote the similarity between the form of the narthex, with its end apses, and a pair of tongs or forceps.

57. In the $5^{\text {th }}$ century mosaic, which is located in the east apse, there are shown vine scrolls adorned with white crosses. Since the sacrament of communion entails the signing of the cross on the forehead of the neophyte, using the holy chrism, it would seem plausible that these unusual motifs were intended to affirm the presence of the $\mathrm{H}$ oly Spirit in the sacrament. The frescos that were located on the west side of the narthex, showed bucolic scenes of shepherds with their flocks, a typical allegory of Christ and the church. The post-baptismal sacrament of Confirmation signals the descent of the $\mathrm{H}$ oly Spirit upon the neophyte and therefore affirms entry into the community of the Church. Following baptismal immersion, it was general practice in the Early Church for all newly initiated to don a white robe before being "marked" with holy chrism in the consignatorium. "The donning of white robes is not only a reminder of cleanness, and of 'newness' of baptism, but also presents a spectacle of the 'angel's glorious beauty'." Cramer, Baptism and Change, pp. I54-155. In view of the solemnity of the post-baptismal rite it would seem likely that the open colonnaded narthex was periodically closed. According to Giovanni Giovenale, a $4^{\text {th }}$ century relief from a sarcophagus, found in the vicinity of the Lateran complex, contains a representation of the baptistery in which heavy draped curtains are shown flanking the prominent entrance. Giovenale, II Battis tero $L$ ateranence, $p$. Io. If Giovenale's assertion is correct, then it is concei vable that these curtains were specifically intended to conceal the interior of the narthex during the administering of the sacrament.

58. This seems consistent with the interpretation of the $4^{\text {th }}$ century relief in which the figure on the left is represented with his back turned to the entrance of the baptistery as if process- 
Taking into consideration the sequence of rituals in the Constantinian Baptistery, from water immersion in the octagonal space to the receiving of the holy chrism in the narthex, it seems likely that the narthex also functioned as the exit..$^{88}$ Following the rites of baptism and confirmation, the newly initiated would process to the nearby Lateran Basilica to participate in the sacrament of the Eucharist. In Early Christian liturgy, the celebration of the Eucharist typically took place immediately after the baptismal ceremony. ${ }^{59}$ Whilst the topographical relationship between the Lateran Baptistery and Basilica appears somewhat ambiguous in plan, in which the former is sited on the north-west corner of the latter, it is clear that both buildings were "ritually" connected through the closely ordered sequence of the sacraments; of baptism, confirmation and the Eucharist. The need to ensure continuity of ritual was evidently a central religious and political concern, particularly in view of the large numbers of catechumens being converted. Early participation of the neophyte in the sacrament of the Eucharist was probably an important priority to both emperor and bishop since it ensured the future viability of the Christian empire and its state religion. The sacrament of confirmation provided the critical link in the sequence of rituals, between initiation and full participation in the C hurch. Whilst it may be stretching the argument somewhat, it could be said that the sacraments of baptism and confirmation constituted a form of ritualized contract, by which the neophyte declares by his

ing away from the narthex. Sible D e Blaauw takes a different view of the dating of the narthex and by implication its function, based on the contention that it was built after the $4^{\text {th }}$ century. $\mathrm{H}$ e challenges Pelliccioni's analysis of the archaeological evidence by suggesting that the consignatorium and exit were located elsewhere during the $4^{\text {th }}$ century, in one of the adjacent rooms of the extant D omus (D e Blaauw, Cultus et D écor, vol. II, fig. 6).

59. This integration of the sacraments is given clear architectural expression in the celebrated $5^{\text {th }}$ century Christian complex at Salona in Dalmatia which contains a polygonal baptistery, and large basilica along with what is thought to be a catechuminium and consignatorium. E. D yggve, "Le baptistère de la Basilica U rbana à Sal one d'après les fouilles de I949", Atti del V Congresso Internazionale di Archeologia Cristiana, I954, pp. I89-234; Ejnar D yggve, H istory of Salonitan Christianity, O slo, Instituttet For Sammenlignende Kulturforskning, I95I.

6o. Such a political reading of the rite was not unique to the period of Constantine but can also be seen in a more explicit way in Charlemagne's version of imperium, in which the Frankish king instigated a vigorous program of Christianization of the Saxons, where military occupation and baptism effectively went hand in hand. Glenn C.J. Byer, Charlemagne and Baptism: A Study of Responses to the Circular Letter of $8 I I / 8 I 2$, Oxford, International Scholars Publications, 1999, p. 35 . 
DOI: http://dx.doi.org/10.22201/iie.18703062e.2002.80.2105

entry into the $C$ hurch a binding loyalty to the new Christian empire.60

In view of Constantine's likely personal interest in the conversion of the Roman populace to the new Christian faith, it is extraordinary that he was not baptized until his last days, indeed on his deathbed in $\mathrm{AD} 337$. O ne can only imagine the ramifications of this delay in Constantine's dealings with the $\mathrm{C}$ hurch. ${ }^{6 \mathrm{~T}} \mathrm{~T}$ his troubling fact gave rise to a myth that Pope Silvester baptized the emperor at the Lateran, and that the ritual miraculously cured Constantine of leprosy. ${ }^{62} O$ ne possible explanation for Constantine's delay in his baptism is highlighted in the meaning of the rite in Primitive Christianity. O ur main sources here are the $3^{\text {rd }}$ century writings of $H$ ippolytus, his Apostolic Tradition, and Tertullian's D e Baptismo. Active as a priest in Rome under the Severan emperors, $H$ ippolytus provides a lengthy account of the rite that Peter $\mathrm{Cramer}$ summarizes in the following terms:

the idea of baptism as an isolated, unrepeatable moment is the reason for "clinical" or deathbed baptism - the practice of taking baptism as late as possible before dying, so as to avoid the arduous task of keeping to the baptismal vow. And this was a choice not between many possible interpretations, but between two simplified orders of existence: the pagan and the Christian; the bad and the good. ${ }^{63}$

6r. Johannes A. Straub, "Constantine as Koinos Episkopos: Tradition and Innovation in the Representation of the First Christian Emperor's M ajesty," Dumbarton Oaks Papers, 2I (1967), pp. 39-55. An indication of this can be seen in the Ecumenical Council that Constantine convoked at his palace in $\mathrm{N}$ icea. As Johannes Straub points out, the fact that Constantine was not baptized would have made it very difficult for members of the clergy to accept him as a Christian, let alone recognize his authority as self-declared "civic bishop" and overseer of Church policy.

62. The story, which gave legitimacy to the "D onation of Constantine," was generally accepted as authentic for many years by the $C$ hurch, despite dissenting voices. In fact it was only finally repudiated by the humanist Lorenzo Valla in the ${ }_{1}{ }^{\text {th }}$ century. D e falso credita et ementita Constantini donatione, W. Setz (ed.), M onumenta Germaniae H istorica, Q uellen zur G eistesgeschichte des M ittelaters, Io (W eimer, 1976), esp. pp. iा7-II8. The event of the emperor's supposed baptism at the Lateran became the subject of a number of painted repre sentations, notably the ${ }_{13}{ }^{\text {th }}$ century fresco in the Chapel of St. Silvester in Santi Q uattro Coronati, located on the $\mathrm{C}$ aelian $\mathrm{H}$ ill, and the more familiar depiction, dating from the ${ }_{1} 6^{\text {th }}$ century, by Giulio Romano in the Sala di Costantino in the Vatican.

63. Cramer, Baptism and Change, pp. 15-16. 
H ence, baptism meant a complete break from a former existence, the observance of which demanded constant vigilance to overcome complacency and deviation. This uncompromising view of the meaning of the rite under $\mathrm{H}$ ippolytus is clearly a response to the belief that Christian faith carried with it the risk of persecution and even death. Baptism alone ensured salvation. This is given added poignancy in Tertullian's mortuary symbolism of the rite, where martyrdom is construed as a substitute to baptism since it ensures salvation through the spilling of the victim's blood. Even though Constantine had formulated the Edict of $\mathrm{M}$ ilan, that declared the end to all Christian persecutions, it seems that the eschatological significance of the rite as a once-in-lifetime transition persevered in Early Christianity and was given a new political dimension. Consequently, for an emperor involved in secular and sacred matters, the personal commitments demanded of conversion would have seriously compromised his position as ruler, particularly at this critical time of political uncertainty and religious change.

This interpretation of the rite during the period of Constantine becomes problematic when we examine it in the light of the emperor's perceived relationship to Christ. Various claims have been made about this relationship, the most controversial suggesting that Constantine sought to present himself not simply as a temporal ruler and Christian pontifex maximus but as the "I ${ }^{\text {th }}$ apostle": "Christ's vicar on earth, and like his pagan predecessors - a thought abhorrent to later generations- an aspect of Divinity incarnate, the Invincible Sun, the Seat of Justice."64 Krautheimer articulates this view in the light of Constantine's burial in the Church of the Apostles in Constantinople under the altar. Located at the most sacred part of the building, at the crossing, Constantine's tomb was doubtless intended to be a source of

64. K rautheimer, Early Christian and Byzantine Architecture, pp. 72-73.

65. I bid., p. 73. This, as Krautheimer points out, became intolerable and led to Constantine's remains being transferred to a separate adjoining mausoleum.

66. D uring Early Christianity the ceremony of consecratio revealed a conflict between divination and human dominion that was only resolved in Christian Byzantium. M oreover, it "was this relevance of speculation on the afterlife of the statesman and ruler which, in late antiquity, made it possible for most Christians to accept - although with many reservations and restatements- some special position for the emperor in heaven. In doing so, the C hristians, in their views of the imperial afterlife, abandoned the reservations about the emperor's status after death which were formulated in the consecratio procedures." M acC ormack, Art and Ceremony in Late Antiquity, pp. 95-96. Constantine's understanding of his own baptism 
devotion, "as much as or more than the Eucharist cel ebrated nearby." 65

If we interpret this bold gesture as evidence of Constantine's conviction in his own immortality and even divinity then, by implication, his deathbed baptism could be construed as a Christian type of imperial consecratio, the funeral ceremony of the emperor that affirms his deification. ${ }^{66} \mathrm{~W}$ hatever reasons prompted Constantine to delay his baptism, it seems clear that the emperor saw himself as the earthly "caretaker" of God's community, and that his baptism provided entry into an exclusive domain of sanctification and even immortality. Such a venerated status of the emperor was to become fully developed in the Byzantine court, culminating in Justinian's imperium.

\section{Baptism and Confirmation in $4^{\text {th }}$ and $5^{\text {th }}$ Century Rome}

By the $5^{\text {th }}$ century, the relationship between confirmation and baptism at the Lateran acquired a more elaborate symbolic and ritual connection. Besides the addition of adjoining chapels to the Baptistery, dedicated to St. John the Baptist and St. John the Evangelist, Pope H ilarius (46I-468) also converted and consecrated a nearby garden pavilion, thought to date from the second or third centuries, into a chapel dedicated to the Holy Cross. Richard Krautheimer suggests that it housed the relic of the cross, earlier kept at

could be construed as a conflation of Christological notions of afterlife and the imperial practice of conferring divinity upon the deceased emperor. This is implied in what Constantine is reputed to have said following his death-bed baptism: "N ow I know that I am truly blessed. N ow I feel assured that I am accounted worthy of immortality and am a partaker of D ivine Light." Eusebius, De Vita Constantini, IV , p. 63. Alistair Kee infers such a meaning in his interpretation of Eusebius' account of Constantine's life: “... Eusebius speaks of C onstantine passing directly into the eternity of rule in heaven. D oes this explain the Emperor's view of baptism? H e did not see it as being washed in the blood of the Lamb. Christ was no mediator for him. The significance of the event lies in its timing. He wanted to be baptized but postponed it till the end of his life. This has normally been taken to mean that he wished at this later stage to have, through baptism, his sins forgiven. But this is not what Constantine had in mind. Rather, he sees baptism as the conferring of immortality and that comes appropriately at the end of his rule..." Alistair Kee, Constantine versus Christ, London, scм, 1982, p. 58.

67. Krautheimer, Thre Christian Capitals, p. is5. 


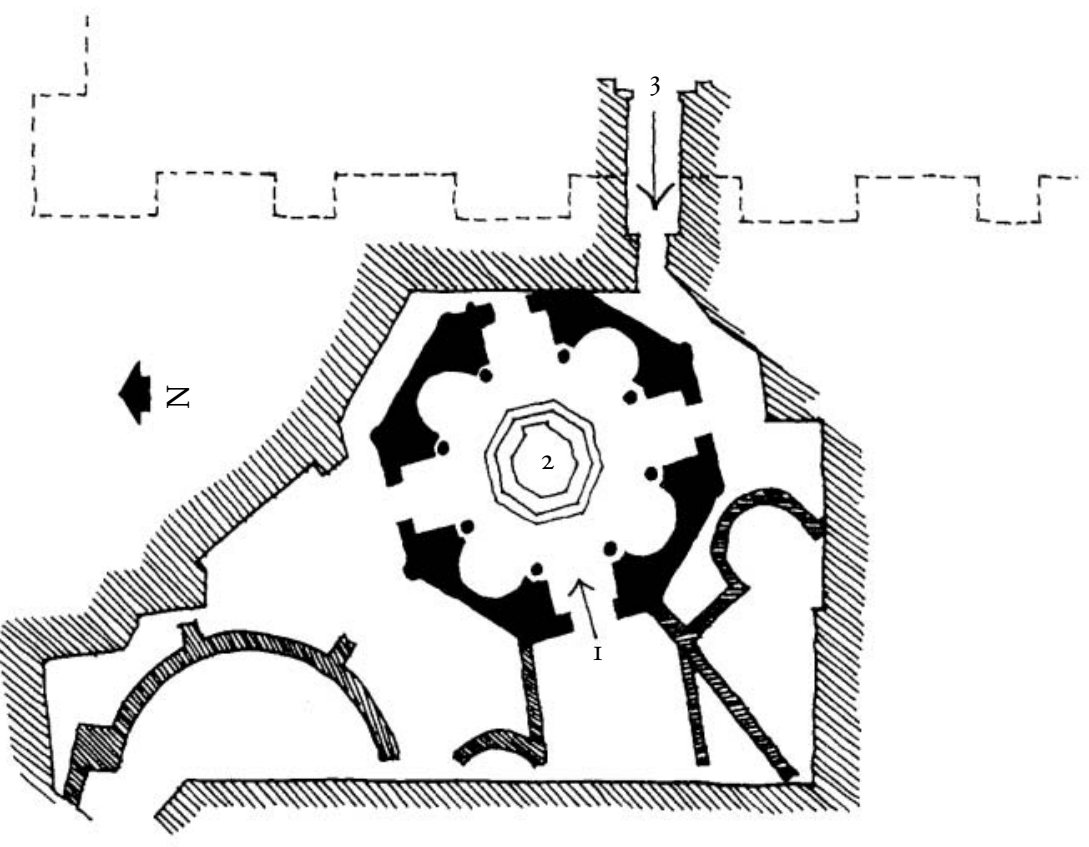

9. Plan of the archaeological excavations of the octagonal Ambrosian Baptistery (2), indicating original entrance (I) to the baptistery from the south aisle of the adjoining Basilica of Santa T ecla and the present entrance (3) to the underground excavations from the later Gothic cathedral (shown dotted); based on excavations carried out by the 'Soprintendenza ai M onumenti per la Lombardia' and drawn by author.

Santa Croce in Gerusalemme and brought to Rome by $\mathrm{H}$ elena, Constantine's mother. ${ }^{67}$ Cross-shaped in plan, with small octagonal alcoves, the building was adorned with rich mosaics in the vault and marble revetments along the walls. D estroyed in the late ${ }_{1} 6^{\text {th }}$ century, the interior space of this building was recorded in a drawing by Giuliano da Sangallo, which shows

68. For a discussion of the symbolic significance of caryatids and seraphim in domical buildings in Late Antiquity and Early Christianity see Karl Lehmann, "The D ome of H eaven", Art Bulletin, vol. XXVII, no. i (1945), pp. I-27.

69. See P. Lauer, Le Palais de Latran, Paris, I9I. Lauer claims that the chapel is the earliest example of an inscribed cruciform plan type. 
representations of caryatids in the vault at each corner holding up an oculus or celestial ring. ${ }^{68}$ The conversion of this essentially pagan structure into a Christian chapel required, it seems, little alteration except the insertion of a cross in the mosaic of the vault. ${ }^{69}$ It is likely that this consecration was prompted by the need to provide a larger space for the consignatorium to accommodate increasing numbers of neophytes. It may also have been converted to overcome the inherent problems of circulation resulting from administering confirmation in the entrance narthex. Besides the convenience of its location in relation to the baptistery, the chapel of Santa Croce would also have been symbolically an ideal place for a consignatorium, considering that confirmation entails the marking of the holy chrism on the foreheads of the neophytes in the form of the cross. ${ }^{70}$

Prior to Pope H ilarius's additions and alterations to the Lateran Baptistery an earlier $5^{\text {th }}$ century pope, Sixtus III (432-440), had substantially reconstructed large parts of the octagonal Baptistery. This entailed the relocation of the columns, originally donated by Constantine, from the inner angles of the original enclosure to the parapet surrounding the font. These columns, as shown in Lafreri's drawn reconstruction of the Sistine Baptistery, created an inner ambulatory to support a central dome. This structure has largely survived to this day, albeit with added alterations from the $16^{\text {th }}$ and $17^{\text {th }}$ centuries. From the evidence of ${ }_{1} 6^{\text {th }}$ century drawings it would seem that the original interior embellishments of the Sistine Baptistery, comprising marble revetments on the walls and most probably vaulted mosaics, were influenced by the interior of the $4^{\text {th }}$ century Santa Costanza..$^{71} M$ oreover, the obvious formal similarities between Sixtus III's remodeling of the Lateran Baptistery and the earlier imperial mausoleum, in the use of inner ambulatory, central dome and the elaboration of the pronaos/narthex "a forcipe", further suggest that the latter was consciously used as a model for the former. ${ }^{72} \mathrm{~T}$ he reason for this may not just be a desire to emulate Constantinian precedent, a point

70. The space connecting the Baptistery to Santa C roce was adapted to form an elaborate fountain courtyard, also executed under Pope Hilarius, and constructed from spoils taken from other ancient buildings (Krautheimer, Three Christian Capitals, p. IIs). This could be compared to the famous pine-cone fountain in the Atrium of St. Peter's Basilica that similarly celebrated the cathartic effects of holy water on the neophyte.

7I. H enri Stern, "Les M osaïques de l'Église de S. Costance de Rome", Dumbarton 0 aks Papers, I2 (1958), pp. I57-208.

72. Krautheimer, Early Christian and Byzantine Architecture, p. 94. 
that can certainly be made elsewhere in Sixtus III's building projects, but may also relate to a deeper symbolic affinity between both buildings.

An inference of this can be seen in a schism that took place under Constantius II in the mid $4^{\text {th }}$ century, between the bishop Liberius and the antipope Felix II. H aving succeeded Julius I to the papal throne in AD 352, Liberius was embroiled in a bitter conflict that centered around Constantius's Arian sympathies and the resistance of the bishops in the West to eastern Christological doctrine. Constantius sought Felix's election and in one contemporary description the antipope was actually elected bishop in the imperial palace on the Palatine in Rome.73 The rivalry between Liberius and Felix involved, as John Curran points out, "the association of particular areas of the city with one or other of the disputants." This Curran calls a "schismatic 'fracture' of the Christian topography of the city" which "was to influence the monumental Christianization of the city..." 74 Prior to Liberius' exile from Rome, as a consequence of this "fracture", he was forced to reside at the Vatican. This naturally meant than Liberius could not administer baptism at the Lateran. It was suggested by $D$ amasus, a presbyter and later successor to the papal throne, that a baptistery be installed at St. Peter's Basilica to meet this need.75 H owever, as already pointed out, this was not actually constructed until $D$ amasus himself became pope. The delay may have been due to the fact that Liberius finally left Rome, resulting in his opponent taking control of the city and the $\mathrm{H}$ oly See. $\mathrm{O}$ ne consequence of this was that Felix could administer the rite of baptism at the Lateran, as was the prerogative of the bishop of Rome. According to the Liber Pontificalis, Liberius

73. Curran, Pagan City and Christian Capital, p. I32.

74. Ibid., p. I30.

75. De Blaauw, Cultus et D écor, vol. II, p. 489.

76. It was only the previous year, $\mathrm{AD} 357$, that the emperor had visited Rome in an attempt to find a solution to this schism.

77. D uchesne, Liber Pontificalis, vol. I, p. 207.

78. Santa Costanza is also thought to have been used as a baptistery during the later schism of Pope Boniface I against his rival pope Eulalius, during Easter of $\mathrm{AD} 4 \mathrm{I} 9$. For a balanced account of the evidence see Stern, "Les M osaïques de l'Église de S. Costance de Rome", pp. I64-165. The idea of an imperial mausoleum such as Santa Costanza being used as a baptistery is used to support a theory that the domical mausoleum on the west side of St. Peter's Basilica (later S. Petronilla), was the original place of the Petrine baptistery, which was subsequently relocated to the north transept by Leo III. De Blaauw, Cultus et Décor, pp. 488489, n. 208. 
was allowed to return to Rome in 358 , following a compromise agreement with the emperor Constantius II. ${ }^{6}$ Liberius's claim however to the bishopric was still challenged by Felix. This forced Liberius to seek refuge in the cemetery of Sant'Agnese on the outskirts of Rome along the via N omentana. 77 It was here that Liberius administered the sacrament of baptism for his supporters, most probably in the M ausoleum of Santa Costanza. ${ }^{78}$ Besides being a suitable setting in which to contest Felix's activities at the Lateran, the choice of the imperial mausoleum could al so be seen as a gesture of acknowledgment of imperial authority in the affairs of the Church at a time when the exiled pope most needed the support of the emperor. What becomes apparent in this papal schism is the crucial role played by baptism in reaffirming the status of the bishop, and the way in which this finds expression in the territorial rival ries between the Lateran and the burial sites of the venerated martyrs, of St. Peter's Basilica and St. Agnese fuori le mura.

\section{Augustine, Ambrose and Theodosius I}

H ippolytus's principle of the two "ways" in his catechism, of the pagan and Christian, of which the latter is the only true way, underlies his rejection of participation in a larger social realm. Indeed, $\mathrm{H}$ ippolytus repudiates the prevailing social milieu that he sees as the cause of one's estrangement from G od. 79

At one level, this rejection merely re-affirms the belief in a spiritual community that transcends the physical world. At the same time, however, $\mathrm{H}$ ippolytus's denial of the city as a setting conducive to meaningful Christian participation can also be explained in the more immediate context of $3^{\text {rd }}$ century Rome when it was dangerous to declare one's faith in public. Taken generally, $\mathrm{H}$ ippolytus's strongly anti-participatory view of the Christian in the larger social realm is the very antithesis of Constantine's vision of a Christian empire in which the city played a key role.

Seen from these two diametrically opposed viewpoints, one based essen-

79. Cramer, Baptism and Change, p. 35. As Cramer points out: "[H ippolytus] paints his well-known picture of the Christian community, transient, alien, as the soul is to the body, living in the cities but not of them, quickened by suffering and persecution, straining with knowledge towards the incorruptible, the just and the sinless Christ". Ibid., p. 36. 
tially on the autonomy of the individual in spiritual contemplation and the other on corporate participation in an empire of faith, it is revealing how the idea of the two cities became such an important metaphor for human salvation in St. Augustine's writings. $\mathrm{H}$ ere, we witness a move away from the transformational, once in a life time, effect of baptism in the Hippolytan creed, constituted as a mode of theophany, to an emphasis on baptism as spiritual preparation, what Augustine calls the peregrinatio. ${ }^{80}$ In this spiritual journey we graduate from the city of walls, the urbs, to ecclesia or community of citizens. The latter is the inward city without outward physical form that responds to the yearning of the human spirit for divine grace. In this transition, the earthly city of sin is transformed to its antitype, the image of the heavenly city. Augustine paints a picture of a symbolic topography, in which "fallen Rome" is its initial point of reference and departure. This journey begins, appropriately, in the Catechumenate, the period of preparation and instruction prior to baptism. Augustine emphasizes, in his D e catechizandis, the longevity of this pre-baptismal instruction that culminates in a baptismal rite that is penitent rather than "exorcistic".

Augustine's own baptism in M ilan by St. Ambrose, Bishop of M ilan, was an auspicious event in Christian conversion since its significance extended far beyond Augustine's personal declaration of faith. This was due to important political and theological developments. Like Augustine, Ambrose was pre-occupied with the mysteries of baptism, searching to redefine the essential eschatological meanings of the rite through ritual and homily. An understanding of the significance of baptism in Ambrose's theology requires an appreciation of the bishop's attitude towards the relationship between imperium and sacerdotium. This is clearly highlighted by an incident that took place in M ilan during his bishopric:

We know that on one occasion the Emperor Theodosius, attending $M$ ass in $M$ ilan, did not withdraw with the rest of the laity after the oblation of gifts but remained in the sanctuary. St. Ambrose noted this and sent one of his deacons

8o. De trinitate libri XV, F. D ekkers \& J. Fraiponts (eds.), Turnhout, I968, I4.I7, p. 454. The Bishop of $\mathrm{H}$ ippo examines this notion of spiritual pilgrimage in his famous Confessions and The City of God. The former work is a meditation on the individual's journey to salvation, moving from pagan rhetoric to philosophy, whilst the latter, it could be argued, concerns the idea of corporate salvation. 
to inquire, "if the Emperor wanted anything". Theodosius replied that he desired to attend the sacred mysteries. Whereupon the great bishop of M ilan advised him that the place inside the canelli, i.e., the sanctuary was reserved for the clergy only and requested the emperor to leave because his place was with the rest of the laity. "The purple," Ambrose added, "makes emperors but does not make priests." Theodosius complied graciously, remarking only that the reason for his remaining in the sanctuary was not arrogance but custom: in Byzantium the emperor at that time attended the eucharistic rite in the sanctuary. ${ }^{8 \mathrm{I}}$

The defiance of the privileged status of the emperor in the preparation of the Eucharist, in the offertory procession, was indicative of Ambrose's conviction of the need to separate $C$ hurch from state. W hat Constantine had earlier sought to establish in the conjoining of sacerdotium and imperium had by the end of the $4^{\text {th }}$ century become increasingly unacceptable in the West. This has to be seen in the light of $\mathrm{M}$ ilan as an imperial city. $\mathrm{M}$ aximian $\mathrm{H}$ eraclius, D iocletian's co-emperor, made M ilan his residence from AD 293 to 305. Later, after Constantine's death, the Augusti ruling the western empire made M ilan their semi-permanent capitol and the city held a key position in the wars between the orthodox and Arian views, up to the end of the $4^{\text {th }}$ century. ${ }^{82}$ Significantly, the conflict between East and West concerning the relationship between sacerdotium and imperium begins in M ilan, as we see in Ambrose's refusal to allow Theodosius to enter the sanctuary. ${ }^{83}$

Underlying Ambrose's numerous church projects in the city, which included a church of the Apostles modeled on the Apostoleion in Constantinople, are important political and religious objectives. These center around the controversial issue of the altar as a burial chamber. According to Ambrose, only the bishop who administers the sacrament of the Eucharist is

8I. Theodoretus, Ecclesiastica historica, V. I7 (PG, LXXXII, I232f.). Quoted in von Simson, Sacred Fortress, p. 3o. See also Kenneth M eyer Setton, Christian Attitude T owards the Emperor in the $4^{\text {th }}$ Century, N ew York, I94I (Columbia U niversity Studies in H istory and Economics), ch. 5.

82. K rautheimer, Three Christian Capitals, p. 62.

83. Ibid., 79 .

84. "Scandalous for a layman and therefore changed by Constantine's son himself, the distinction of that burial place was appropriate for a priest, a concept fully consonant with Ambrose's policy of keeping, within the Church, the emperor in his place among the laity." Ibid., p. 7I. 
entitled to be buried underneath the altar, an assertion which Krautheimer claims was a "riposte" to Constantine's first burial place under the altar of the Apostoleion in Constantinople, highlighted earlier. ${ }^{84}$

In his battles with heresy and confrontations with imperial rule Ambrose focused his attention on strengthening the Christian faith, of which the sacrament of baptism was central. This is seen in two important ways, first in his discourses, De Sacramentis, and secondly in his involvement in the iconography of the baptistery of Santa Tecla. Ambrose's sermons to the neophytes evoke an urgency about the rite of baptism; “... he who comes to baptism does not make confession of his sins, and yet he does make confession of all his sins in the sense that he desires baptism so as to be saved, to pass from blame to grace." ${ }^{5} \mathrm{~T}$ his emphasis on the saving grace of God is underpinned by Ambrose's formalization of the symbolism of the octagon as highlighted in an inscription attributed to the bishop of M ilan:

$\mathrm{H}$ e put up the eight-walled temple and set it to holy use. In this gift of eight sides it was only right to put an eight-sided font: and so the hall of the baptized was built in eights, because in its salvation itself made full circle back to its own people, making its way by the light of resurgent Christ, who scatters the cloister of death and lifts from the grave those who have breathed their last breath, and, resolving the repentant guilty of the stain which is their wrong-doing has washed it to nothing in the irrigation of the clean-streaming fountain. ${ }^{86}$

It is important to appreciate the significance of this symbolism in the Ambrosian rite of baptism, especially when seen in the larger context of developments in the baptistery in Early Christianity. This is given concrete expression in the Baptistery of Santa Tecla where it has been claimed Bishop Ambrose baptized St. Augustine. ${ }^{87}$ Sited at the east end of Santa Tecla, the Ambrosian Baptistery shows a similar topographical relationship with respect to its basilica to that between the Lateran Baptistery and basilica discussed earlier. M ore specifically, the form of the Ambrosian Baptistery

85. D e sacramentis, 3.12, p. 76. Q uoted in Cramer, Baptism and Change, p. 65.

86. Dictionnaire d'archéologie chrétienne et de liturgie, F. Cabrol, H. Leclercq et al. (eds.), Paris, 1907-53, vol. I, col. 1386.

87. For an examination of the evidence see "D ove fu battezato Sant'Agostino", Archivio Storico Lombardo, 1966, XCI-XCII, p. 225. 
alludes to more local references. Considering the bishop's fierce opposition to imperial jurisdiction over the affairs of the Church, it is ironic that the modeling of the octagonal building should show signs of influence of the imperial mausoleum of M aximian. Located outside the city walls, this mausoleum was later incorporated into the Romanesque church of San Vittore al Corpo. From excavations it is known that the octagonal wall enclosure consisted of alternating rectangular and semicircular niches in much the same way as the enclosure of Ambrose's octagonal baptistery. ${ }^{88}$ The question of whether Ambrose saw any conflict in this obvious similarity with the imperial mausoleum can only be speculated. What should be emphasized however is that by the late $4^{\text {th }}$ century in the West the imperial associations of certain building forms, such as the centralized domical building and the triconch, had largely been superceded by $\mathrm{C}$ hristian symbolism. As Peter $\mathrm{C}$ ramer states:

So much for the Roman inheritance, of which the effect was probably in the end an unspecified residue in the city's mind of romanitas, rather than a catalogue of exact senses. Beside it are the liturgical ideas held fast in the baptistery, above all the two great liturgical ideas of death-and-resurrection and rebirth. ${ }^{89}$

In conclusion, this paper has sought to highlight the manner in which developments in the iconography of the Early Christian baptistery, from their primitive $\mathrm{C}$ hristian origins to St. Ambrose, reflect larger political and territorial relationships between sacerdotium and imperium. Under Constantine, this initially entailed the conscious separation of pagan and Christian traditions by the creation of extra-territorial basilicas near, or outside, the city walls. By displacing religious activity, from its traditional settings in the sacred precincts of ancient Rome to the distant locations of the Lateran complex and venerated cemeteries fuori le mura, participation in Christian worship necessitated leaving the city behind and its temporal world. This shift from the traditional urban context of religious life to sub-urban or rural locations was accompanied by an "internalization" of sacred space under Constantine, in the form of large basilicas. The development of the freestanding baptistery was integral to this transformation of sacred space, from

88. For information on the archeological evidence of the mausoleum see K rautheimer, Three Christian Capitals, p. I42, n. 3 .

89. Cramer, Baptism and Change, p. 270. 
an outwardly to an inwardly defined setting. The Constantinian Baptistery functioned at one level as a ritual and symbolic ante-room to the "palatium" of the Lateran complex.

At the same time, Early Christian initiation, along with pre- and postbaptismal rituals in the catechumenium and consignatorium, provided an articulated spatial-temporal context where the transition from a pagan to a Christian life could be expressed as an irreversible passage from sin to grace. This study has highlighted the problematic nature of C hristian conversion in the light of a largely conservative pagan community resistant to change. Accordingly, the politics of division and difference, discernible in Constantinian Rome, provided not so much an unbridgeable divide between two antithetical traditions but rather helped foster a rich heterogeneous iconography, whose underlying symbolic intent was anticipatory in nature; it prepared the way for the much-vaunted concordance of imperium and sacerdotium. Baptism constituted one of the principal mechanisms for achieving this goal, which probably explains why the Lateran Baptistery was one of the first, if not the first, building to be constructed by Constantine in Rome.

To realize his vision, however, Constantine had to abandon Rome and to found a new imperial capital along the Bosphorus, whilst in the West the wished-for concordance between church and state was increasingly seen as out of step with Church doctrine, as seen in the case of St. Ambrose. H ence, within the duration of little more than 75 years the question of Roman inheritance became in the West, to reiterate Peter Cramer, "an unspecified residue in the city's mind of romanitas... " Consequently, to be baptized in Ambrosian M ilan carried with it very different political and religious associations to those of Constantinian Rome. These were more firmly grounded in a theological perspective of urban society that was distinct from notions of the state or the imperial cult. St. Augustine's idea of the two cities, of civitas terrena and civitas sancta, is emblematic of this idea of conversion as a lived experience, in which fallen Rome serves as a point of departure. In contrast to the earlier Hippolytan creed of an unmediated situation, of living in but not of the city, or the Constantinian model of a divided topography, St. Augustine's twofold city requires the catechumen to undergo an extended spiritual journey, the peregrinatio. Accordingly, one can no longer assume conversion as a specific spatial-temporal event or as a once in a lifetime experience, as found in earlier doctrines of baptism. Rather, the peregrinatio requires a spiritual attunement to divine grace without the specificities of a 